medRxiv preprint doi: https://doi.org/10.1101/2021.10.04.21264517; this version posted October 5, 2021. The copyright holder for this preprint (which was not certified by peer review) is the author/funder, who has granted medRxiv a license to display the preprint in It is made available under a CC-BY-NC-ND 4.0 International license.

1 Full Title: Development and validation of a multiplex real-time qPCR assay using GMP-

2 grade reagents for leprosy diagnosis

4 Short running head: Multiplex qPCR for leprosy diagnosis

6 Author names and affiliations.

7 Fernanda Saloum de Neves Manta1\%, Thiago Jacomasso² , Rita de Cássia Pontello

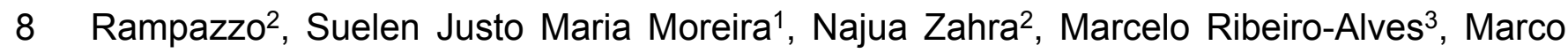

9 Aurélio Krieger ${ }^{2,4}$, Alexandre Dias Tavares Costa ${ }^{2,4, \& *}$, Milton Ozório Moraes ${ }^{1 \& *}$

101 Laboratório de Hanseníase, Instituto Oswaldo Cruz, FIOCRUZ, Rio de Janeiro, Rio de

11 Janeiro, Brazil

$12{ }^{2}$ Instituto de Biologia Molecular do Paraná, Fiocruz, Curitiba, Paraná, Brazil

$13{ }^{3}$ Instituto Nacional de Infectologia Evandro Chagas-Fiocruz, Rio de Janeiro, Rio de Janeiro,

14 Brazil

154 Instituto Carlos Chagas, Fundação Oswaldo Cruz/FIOCRUZ, Curitiba, PR, Brasil.

16 I These authors contributed equally to this work

17 \& These authors also contributed equally to this work

18

* Corresponding authors:

20 1) Alexandre Dias Tavares Costa (Ph.D). 
medRxiv preprint doi: https://doi.org/10.1101/2021.10.04.21264517; this version posted October 5, 2021. The copyright holder for this preprint (which was not certified by peer review) is the author/funder, who has granted medRxiv a license to display the preprint in It is made available under a CC-BY-NC-ND 4.0 International license.

21 Instituto de Biologia Molecular do Paraná / Instituto Carlos Chagas, Fundação Oswaldo

22 Cruz/FIOCRUZ, Curitiba, Paraná, Brasil.

23 Phone: +55-41-3316-3230; E-mail: alexandre.costa@fiocruz.br

2) Milton Ozório Moraes (Ph.D).

26 Laboratório de Hanseníase, Instituto Oswaldo Cruz, FIOCRUZ, Rio de Janeiro, Rio de 27 Janeiro, Brazil

28 E-mail:milton.moraes@fiocruz.br, Telephone contact: +55-21- 25621556.

29

Number of text pages ( 34 ); tables ( 4 ) and figures ( 7 )

Grant numbers and sources of support:

This work was funded by a grants from: Banco Nacional de Desenvolvimento Econômico e

Social (BNDES), contract no. 15.2.0473.1 (Operation \#4.816.864) to MAK, and Novartis

35 Foundation and Leprosy Research Initiative (LRI; 703.15.45), Foundation for Research

36 Support of the State of Rio de Janeiro (FAPERJ;E-26/203.053/2016), Brazilian National

37 Council for Scientific and Technological Development (CNPq; 421852/2017-2018), Brazilian

38 Coordination for Improvement of Higher Education Personnel (CAPES), and by the National

39 Fund for Health/Brazilian Ministry of Health (MS/SCTIE/DECIT; 404277/2012-8 and TED

40 145/2018) to MOM. 
medRxiv preprint doi: https://doi.org/10.1101/2021.10.04.21264517; this version posted October 5, 2021. The copyright holder for this preprint (which was not certified by peer review) is the author/funder, who has granted medRxiv a license to display the preprint in It is made available under a CC-BY-NC-ND 4.0 International license .

\section{Disclosure of conflict of interest}

44 Instituto de Biologia Molecular do Paraná (IBMP) produces the PCR mastermix and some

45 of the oligonucleotides used in the qPCR experiments. In addition, several authors received

46 grants or fellowships from the Brazilian funding agencies CNPq and CAPES. This work was

47 partially funded by grants from BNDES, Novartis Foundation, Leprosy Research Initiative,

48 Foundation for Research Support of the State of Rio de Janeiro (FAPERJ), CNPq, CAPES,

49 and by the National Fund for Health/Brazilian Ministry of Health (MS/SCTIE/DECIT).

50 However, none of the aforementioned institutions had any participation in the present study's

51 design, data collection, analysis, interpretation, or writing of the report and decision to submit

52 for publication.

53

54 
medRxiv preprint doi: https://doi.org/10.1101/2021.10.04.21264517; this version posted October 5, 2021. The copyright holder for this preprint (which was not certified by peer review) is the author/funder, who has granted medRxiv a license to display the preprint in It is made available under a CC-BY-NC-ND 4.0 International license .

55

56

57

58

59

60

61

62

63

64

65

66

67

68

69

70

71

72

73

74

75

76

77

\section{Abstract}

Leprosy is a chronic dermato-neurological disease caused by Mycobacterium leprae, an obligate intracellular bacterium. Timely detection is a challenge in leprosy diagnosis, relying on clinical examination and trained health professionals. Furthermore, adequate care and transmission control depend on early and reliable pathogen detection. Here, we describe a qPCR test for routine diagnosis of leprosy-suspected patients. The reaction simultaneously amplifies two specific Mycobacterium leprae targets (16S rRNA and RLEP), and the human 18S rRNA gene as internal control. The limit of detection was estimated to be 2.29 copies of $M$. leprae genome. Analytical specificity was evaluated using a panel of 20 other skin pathogenic microorganisms and Mycobacteria, showing no cross-reactivity. Intra- and interoperator $\mathrm{C}_{\mathrm{p}}$ variation was evaluated using dilution curves of $M$. leprae DNA or a synthetic gene, and no significant difference was observed between three operators in two different laboratories. The multiplex assay was evaluated using 97 patient samples with clinical and histopathological leprosy confirmation, displaying high diagnostic sensitivity (91\%) and specificity (100\%). Validation tests in an independent panel of 50 samples confirmed sensitivity and specificity of $97 \%$ and $98 \%$, respectively. Importantly, assay performance remained stable for at least five months. Our results show that the newly developed multiplex qPCR effectively and specifically detects $M$. leprae DNA in skin samples, contributing to an efficient diagnosis that expedites the appropriate treatment. 
medRxiv preprint doi: https://doi.org/10.1101/2021.10.04.21264517; this version posted October 5, 2021. The copyright holder for this preprint (which was not certified by peer review) is the author/funder, who has granted medRxiv a license to display the preprint in It is made available under a CC-BY-NC-ND 4.0 International license .

\section{Author Summary}

80

81 Leprosy is a chronic dermato-neurological disease caused by Mycobacterium leprae, an

82 obligate intracellular bacterium. Disease diagnosis is currently performed on skin

83 examinations for clinical signs, bacilli staining in skin smears and invasive skin biopsies.

84 However, the spectrum of clinical manifestations and the low bacterial load can hinder

85 accurate diagnosis, which is critical for providing proper intervention and adequate care as

86 well as for establishing transmission control. Quantitative PCR (qPCR) methods for

87 detecting bacterial DNA are more sensitive and could aid in differentially diagnosing leprosy

88 from other dermatological conditions. In this work, we present a new multiplex qPCR that

89 detects two bacterial genes for the diagnosis and a human gene as an internal reaction

90 control. The new qPCR, developed using GMP-grade reagents, is highly sensitive, specific,

91 reproducible, and stable. The results presented here are the basis of a novel and robust tool

92 with potential to increase the accuracy of leprosy diagnosis in routine or reference

93 laboratories.

94

95 Keywords

96 leprosy; diagnostic; qPCR; good manufacturing practices; validation; neglected tropical

97 diseases; Mycobacterium leprae; internal control 
medRxiv preprint doi: https://doi.org/10.1101/2021.10.04.21264517; this version posted October 5, 2021. The copyright holder for this preprint (which was not certified by peer review) is the author/funder, who has granted medRxiv a license to display the preprint in It is made available under a CC-BY-NC-ND 4.0 International license.

\section{Introduction}

Leprosy is a neglected infectious disease that still represents a public health issue (1) with more the 200,000 cases every year worldwide. Diagnosis is generally late and, although a specific and effective treatment is available, it is likely that transmission occurs before the patient is diagnosed and adequately treated, thus contributing to sustained transmission. The high number of young patients (under 15 years old) and patients with disabilities due to advanced stage of the disease, confirms this hypothesis (1). Furthermore, clinical forms vary to a great extent, from localized (tuberculoid) to disseminated (lepromatous) forms, making diagnosis difficult. Evidence suggests that early diagnosis could prevent transmission and help epidemiological control (2).

Methods such as bacterial load detection by microscopy and histopathological examination have been the main complementary tools for the diagnosis of leprosy (2-4). Classical bacteriological methods cannot confirm leprosy since $M$. leprae does not grow in vitro. In addition, there is no reliable marker to estimate the risk of disease progression $(5,6)$. In this regard, the sequencing of $M$. leprae genome (7) was a milestone towards the improvement of direct $M$. leprae detection, leading not only to better characterization of genomic targets unique to $M$. leprae strains but also to an extensive comparison of different mycobacteria.

At the time of the first sequences became available, the polymerase chain reaction (PCR) technique was laborious and very expensive, averting its universal application. However, as PCR was further developed, it became more affordable, versatile and reliable, with fully automated systems becoming commercially available from different companies (8-10). For tuberculosis, routine tests using PCR are reducing the turnaround time, allowing same day treatment initialization, which might impact resistance prevalence (11-13). Cost-effective 
medRxiv preprint doi: https://doi.org/10.1101/2021.10.04.21264517; this version posted October 5,2021 . The copyright holder for this preprint (which was not certified by peer review) is the author/funder, who has granted medRxiv a license to display the preprint in It is made available under a CC-BY-NC-ND 4.0 International license .

123 nucleic acid detection assays are relatively widespread, but assays for some neglected 124 diseases are still missing. In leprosy, the situation is even more difficult due to reduced and 125 late investments directed to diagnostic tests (14).

126 In the last few years, many studies have been carried out using the PCR technique to detect 127 M. leprae DNA in clinical specimens. PCR have been used especially under challenging 128 diagnoses such as equivocal paucibacillary $(4,15-18)$ or monitoring household contacts $129(19,20)$. In this context, several different targets have been described in an attempt to 130 establish the most sensitive and specific assay (16,20-28). However, most of the PCR 131 protocols were developed, evaluated, and validated using reagents or tests produced 132 without good manufacturing practices (GMP). Also, most of the studies enroll only leprosy patients and do not recruit patients with other common dermatological diseases that are 134 differential diagnosis to leprosy. Thus, the development and validation of an assay over different laboratories has become a necessity.

136 Here, we present the development and validation of a multiplex real-time PCR assay aiming 137 to standardize the leprosy molecular diagnostic assay. The protocol was designed to 138 simultaneously detect two M. leprae targets (16SrRNA and RLEP genes), previously used 139 in several studies $(4,16,19,26,29)$, and one mammalian target (18S rRNA gene), that serves 140 as reaction control (30). Cross-reactivity was evaluated using DNA from 20 related 141 mycobacterial and other skin pathogenic species, and no match was found. The new assay 142 was validated using 97 skin biopsies and an independent panel enrolling 50 samples 143 retrieved from patients previously characterized by clinical examination and histopathology, 144 showed high sensitivity and specificity. The new multiplex PCR was also assessed for 145 quality control standards and the data indicate that the assay is stable and reproducible. The 146 results presented here are the basis of a novel and robust tool with potential to increase the 147 accuracy of leprosy diagnosis in routine or reference laboratories. 
medRxiv preprint doi: https://doi.org/10.1101/2021.10.04.21264517; this version posted October 5, 2021. The copyright holder for this preprint (which was not certified by peer review) is the author/funder, who has granted medRxiv a license to display the preprint in It is made available under a CC-BY-NC-ND 4.0 International license.

\section{Material and methods}

150 Ethics statement

151 The Ethics Committee of the Oswaldo Cruz Foundation approved this study (CAAE: 152 38053314.2.0000.5248, number: 976.330-10/03/2015). Written informed consent was 153 obtained from all patients 18 years or older, or from the parents/guardian of patients under 15418.

Clinical samples

157 Leprosy patients were enrolled from the Leprosy clinic from the Oswaldo Cruz Foundation 158 in the city of Rio de Janeiro, Brazil. Skin biopsies were collected using a 6-mm punch and 159 stored in $70 \%$ ethanol at $-20^{\circ} \mathrm{C}$ until processing.

160 Ninety-seven samples (53 skin biopsies from leprosy patients and 44 skin biopsies from 161 patients with other skin diseases) were used for qPCR tests. Clinical and demographic 162 characteristics of all patients are shown in Table 1. 
medRxiv preprint doi: https://doi.org/10.1101/2021.10.04.21264517; this version posted October 5, 2021. The copyright holder for this preprint (which was not certified by peer review) is the author/funder, who has granted medRxiv a license to display the preprint in It is made available under a CC-BY-NC-ND 4.0 International license.

165 Table 1: Clinical and demographic characteristics of the leprosy and other dermatological 166 disease cases

\begin{tabular}{|c|c|c|c|c|c|}
\hline \multirow[t]{2}{*}{ Characteristics } & \multirow[t]{2}{*}{ Types } & \multicolumn{2}{|c|}{$1^{\text {st }}$ panel } & \multicolumn{2}{|c|}{$2^{\text {nd }}$ panel } \\
\hline & & $\begin{array}{c}\text { Leprosy } \\
\text { group }(n=53)\end{array}$ & $\begin{array}{l}\text { ODD } \\
\text { group } \\
(n=44)\end{array}$ & $\begin{array}{l}\text { Leprosy } \\
\text { group } \\
\qquad(n=35)\end{array}$ & $\begin{array}{l}\text { ODD } \\
\text { group } \\
(n=15)\end{array}$ \\
\hline Gender & Male & 32 & 13 & 25 & 3 \\
\hline & Female & 21 & 31 & 10 & 12 \\
\hline Age & $1-15$ & 2 & 3 & 3 & 1 \\
\hline & $16-30$ & 8 & 7 & 5 & 2 \\
\hline & $31-45$ & 14 & 6 & 11 & 2 \\
\hline & $46-60$ & 20 & 19 & 9 & 9 \\
\hline & $>60$ & 9 & 9 & 7 & 1 \\
\hline WHO classification & PB & 18 & NA & 8 & NA \\
\hline & MB & 35 & NA & 27 & NA \\
\hline Clinical form & $\mathrm{I}$ & 6 & NA & 0 & NA \\
\hline & TT & 1 & NA & 3 & NA \\
\hline & BT & 11 & NA & 5 & NA \\
\hline & BB & 5 & NA & 6 & NA \\
\hline
\end{tabular}


medRxiv preprint doi: https://doi.org/10.1101/2021.10.04.21264517; this version posted October 5, 2021. The copyright holder for this preprint (which was not certified by peer review) is the author/funder, who has granted medRxiv a license to display the preprint in It is made available under a CC-BY-NC-ND 4.0 International license.

Other Dermatological Disease (ODD). Operational classifications [paucibacillary (PB) or multibacillary (MB)].

PB individuals were classified as Tuberculoid (TT), Borderline tuberculoid (BT), Indeterminate (I) and Pure Neural (PN). MB individuals were classified as Borderline-borderline (BB), Borderline lepromatous (BL) or Lepromatous (LL). NA: Not Applicable.

Leprosy patients were defined according to the clinical, bacteriological, and histopathological Ridley-Jopling (R\&J) classification and the operational classification in multibacillary (MB) or paucibacillary (PB) forms according to the WHO (31). Leprosy or other dermatological diseases (ODD) patients were treated according to their respective condition. Leprosy paucibacillary (PB) or multibacillary (MB) patients were treated according to the Ministry of Health recommendations, while ODD patients were treated accordingly for each specific disease.

\section{Replication Study}

To validate the conditions and analysis parameters established with the clinical samples from Oswaldo Cruz's Leprosy Clinic, we tested a distinct collection of 50 skin biopsy samples that were also obtained by the Leprosy Clinic. The second set of samples was sent to the Global Health Institute, École Polytechnique Fédérale de Lausanne, Switerzland, where 
medRxiv preprint doi: https://doi.org/10.1101/2021.10.04.21264517; this version posted October 5, 2021. The copyright holder for this preprint (which was not certified by peer review) is the author/funder, who has granted medRxiv a license to display the preprint in It is made available under a CC-BY-NC-ND 4.0 International license .

185 DNA samples was extracted and was blindly characterized by conventional PCR according 186 to a previously published protocol (32). The extracted DNA was then sent back to the 187 Leprosy Clinic at Oswaldo Cruz Foundation, where it was blindly analyzed with the qPCR 188 developed in the present study. After both PCR analyses were performed, blinding was 189 removed and the results were compared. Of these 50 samples, fifteen samples were from 190 patients with other skin diseases, 27 patients MB leprosy and eight from PB leprosy. The 191 group presented a 1.27:1 ratio of males to females. The mean age was $44.8(+/-17.72 \mathrm{SD})$, 192 and the range was 8-77. Details on the clinical characteristics are shown in supplementary 193 table 1.

\section{Mycobacterial isolates samples}

M. leprae Thai-53 purified from athymic BALB/c (nu/nu) mouse footpads was kindly provided by Dr. Patricia Rosa at the Lauro de Souza Lima Institute, Bauru, São Paulo, Brazil.

Purified DNA from M. leprae was used as positive control and in analytical sensitivity studies.

199 DNA from 21 mycobacterial samples were used for the analytical specificity study. $L$. 200 amazonensis and L. braziliensis was kindly provided by Dr Elisa Cupolillo by the Laboratório 201 de Pesquisa em Leishmaniose (IOC- Fiocruz) and M. avium, M. gordonae, M. manteni, M. 202 africanum subtype I, M. africanum subtype II, M. bovis, M. bovis (BCG), M. canettii, $M$. 203 fortuitum, M. gordonae, M. intracellulare, M. kansasii, M. microti, M. pinnipedii, M. simiae, 204 and M. tuberculosis were kindly provided by Dr. Phillip Suffys at Laboratório de Biologia 205 Molecular Aplicada a Micobactérias (IOC-Fiocruz). 
medRxiv preprint doi: https://doi.org/10.1101/2021.10.04.21264517; this version posted October 5, 2021. The copyright holder for this preprint (which was not certified by peer review) is the author/funder, who has granted medRxiv a license to display the preprint in It is made available under a CC-BY-NC-ND 4.0 International license .

\section{Synthetic DNA}

208 The synthetic DNA (gBlock $\left.{ }^{\circledR}\right)$ was purchased from Integrated DNA Technologies (IDT) and 209 consists of a double-stranded DNA containing the sequences of the three genomic targets 210 (RLEP, 16S, and 18S) (S1 Appendix). The lyophilized DNA was reconstituted to $10 \mathrm{ng} / \mu \mathrm{L}$ 211 (corresponding to $1.83 \times 10^{9}$ copies per reaction) in $\mathrm{TE} \mathrm{pH}$ 8.0, following the supplier's 212 protocol.

\section{DNA extraction}

215 DNA extraction from the biopsies was carried out using DNeasy Blood and Tissue ${ }^{\circledR}$ 216 extraction kit (Qiagen, Germany). The total extracted DNA was quantified with NanoDrop® 217 (Thermo-Fisher Scientific, Waltham, MA, USA) and stored at $-20{ }^{\circ} \mathrm{C}$. M. leprae DNA from 218 nude mice footpad was purified using TRIzol reagent (Life Technologies, Carlsbad, 219 California) following the manufacturers' instructions, as previously described (3). DNA used 220 in the replication study were extracted using QIAmp UCP Pathogen Mini kit (Qiagen GmbH, 221 Hilden, Germany).

223 Standard curve and $95 \%$ limit of detection (LoD $\left.{ }_{95 \%}\right)$ assessment

224 The standard curve was used for determination of the limit of detection and assay stability. 225 A series of 10-fold dilutions was prepared from either M. leprae or synthetic DNA, using DNA 226 purified from human blood obtained from healthy donors as matrix. The dilution series used 227 for the standard curve and the $\mathrm{LoD}_{95 \%}$ determination spans concentrations from 500 $228 \mathrm{ag} /$ reaction to $5 \mathrm{ng} /$ reaction of purified M. leprae DNA, and 1.83 to $1.83 \times 10^{7}$ copies/reaction 229 (equivalent to $0.5 \mathrm{ag} /$ reaction and $5 \mathrm{pg} /$ reaction, respectively) of synthetic DNA. 
medRxiv preprint doi: https://doi.org/10.1101/2021.10.04.21264517; this version posted October 5, 2021. The copyright holder for this preprint (which was not certified by peer review) is the author/funder, who has granted medRxiv a license to display the preprint in It is made available under a CC-BY-NC-ND 4.0 International license.

\section{Quantitative PCR (real-time PCR assays)}

232 A multiplex real-time qPCR assay targeting simultaneously two $M$. leprae regions and an 233 internal reference human sequence was developed. The primers and hydrolysis probes 234 were designed to detect regions from RLEP and 16S rRNA genes (29) from M. leprae, and 235 the human 18S rRNA (30) (Table 2). Reactions were performed on an ABI7500 Standard 236 instrument (Thermo-Fisher Scientific, Waltham, MA, USA), using Multiplex PCR Mastermix 237 (IBMP/Fiocruz PR, Curitiba, Brazil). For each reaction, $5 \mu \mathrm{L}$ of DNA solution was added for 238 a $25 \mu \mathrm{L}$ final volume. Reaction mixtures were prepared in triplicates and amplified at $95{ }^{\circ} \mathrm{C}$ 239 for $10 \mathrm{~min}$, and 45 cycles of $95^{\circ} \mathrm{C}$ for $15 \mathrm{sec}$ and $60^{\circ} \mathrm{C}$ for $1 \mathrm{~min}$. All reactions included a 240 positive control (mouse foot-pad M. leprae DNA and/or high-bacterial load lepromatous 241 leprosy patient purified DNA), and water as a non-template control (NTC; PCR reaction 242 without any template DNA).

244 Table 2: Sequences, concentration, and fluorophores of the oligonucleotides contained in 245 the multiplex qPCR assay.

\begin{tabular}{|c|l|c|c|}
\hline \multirow{2}{*}{ Target } & \multicolumn{1}{|c|}{ Sequences } & $\begin{array}{c}\text { Final } \\
\text { concentration }\end{array}$ & Fluorophore \\
\hline 16SrRNA & Forward: 5'-GCATGTCTTGTGGTGGAAAGC- 3' & $0.5 \mu \mathrm{M}$ & FAM \\
& Reverse: 5'-CACCCCACCAACAAGCTGAT- 3' & $0.5 \mu \mathrm{M}$ & \\
& Probe: 5'-CATCCTGCACCGCA-3' & $0.2 \mu \mathrm{M}$ & \\
\hline RLEP & Forward: 5'-GCAGCAGTATCGTGTTAGTGAA-3' & $0.2 \mu \mathrm{M}$ & VIC \\
& Reverse: 5'-CGCTAGAAGGTTGCCGTAT-3' & $0.2 \mu \mathrm{M}$ & \\
& Probe: 5'CGCCGACGGCCGGATCATCGA-3' & $0.1 \mu \mathrm{M}$ & \\
\hline 18s RNA & Forward: & $0.06 \mu \mathrm{M}$ & CY5 \\
& GAAACTGCGAATGGCTCATTAAATCA- 3' & $0.06 \mu \mathrm{M}$ & \\
\hline
\end{tabular}


medRxiv preprint doi: https://doi.org/10.1101/2021.10.04.21264517; this version posted October 5, 2021. The copyright holder for this preprint (which was not certified by peer review) is the author/funder, who has granted medRxiv a license to display the preprint in It is made available under a CC-BY-NC-ND 4.0 International license.

\begin{tabular}{|l|l|l|l|}
\hline & $\begin{array}{l}\text { Reverse: 5'-CCCGTCGGCATGTATTAGCTCT-3' } \\
\text { Probe: 5'GGAGCGAGCGACCAAAGGAACCA-3' }\end{array}$ & $0.03 \mu \mathrm{M}$ & \\
\hline
\end{tabular}

\section{Stability}

249 The stability of the new multiplex qPCR was evaluated the synthetic DNA template diluted 250 in TE to the concentrations of approximately $2 \times 10^{8}, 2 \times 10^{7}, 2 \times 10^{6}, 2 \times 10^{6}, 2 \times 10^{5}, 2 \times$ $25110^{4}, 2 \times 10^{3}, 2 \times 10^{2}, 2 \times 10^{1}, 10,5$, and 2.5 copies per reaction.

252 All reagents (oligomix 25X and qPCR mix) were maintained in independent aliquots at -20 $253{ }^{\circ} \mathrm{C}$ at the Leprosy Laboratory (Fiocruz-RJ). Tests with the dilution series described above 254 were repeated weekly for the first month, and then once a month for five months.

\section{Data Analyses and Statistics}

257 Qualitative (diagnostic sensitivity and specificity, accuracy) and quantitative (intra- and inter258 laboratory repeatability and reproducibility, analytical sensitivity and specificity) validation 259 tests were performed. The $95 \%$ limit of detection $\left(\operatorname{LoD}_{95 \%}\right)$ was calculated by fitting a Probit 260 model to the estimated detection probabilities. Data were processed and analyzed using 261 customized scripts for R version 3.5.1 (downloaded from http://www.Rproject.org/). 
medRxiv preprint doi: https://doi.org/10.1101/2021.10.04.21264517; this version posted October 5, 2021. The copyright holder for this preprint (which was not certified by peer review) is the author/funder, who has granted medRxiv a license to display the preprint in It is made available under a CC-BY-NC-ND 4.0 International license.

\section{Results}

\section{Analytical performance}

Primers and hydrolysis probes designed to target $16 \mathrm{~S}$ rRNA and RLEP sequences of $M$. leprae were tested in multiplexed reactions to concomitantly detect the human $18 \mathrm{~S}$ rRNA sequence. Optimal fluorescence thresholds were chosen based on the common practice that it should be positioned on the lower half of the fluorescence accumulation curves plot

270 from the 10-fold dilutions, crossing most if not all fluorescence signals on the exponential 271 segment of the curve on a logarithmic scale (figure 1). Therefore, after setting the baseline 272 to the automatic function, fluorescence threshold values chosen for determining $C_{p}$ 273 (Crossing point) values for each target were set to intercept the positive controls and avoid 274 the negative ones, being established as follows: 0.2 for RLEP, 0.15 for $16 \mathrm{~S}$ rRNA, and 0.16 275 for $18 S$ rRNA.

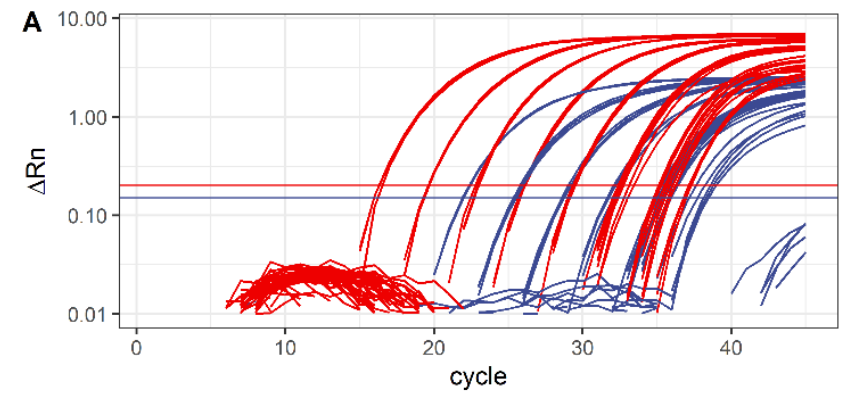

- 16S - RLEP

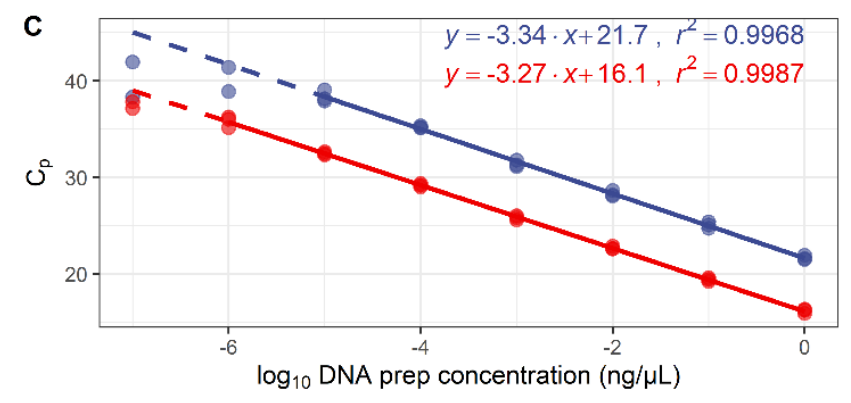

$-16 \mathrm{~S}-\mathrm{RLEP}$

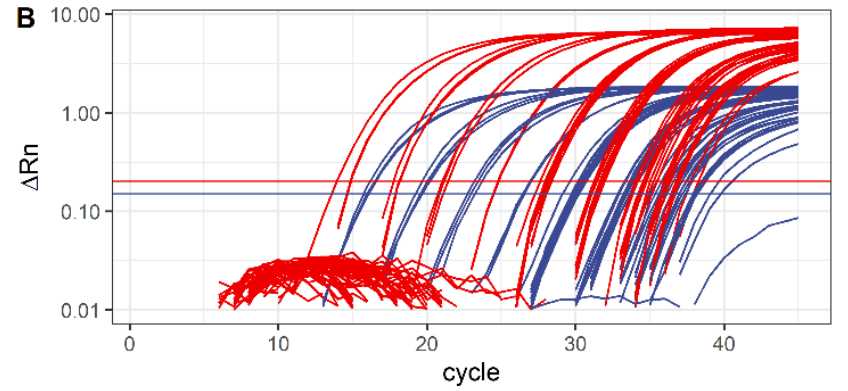

- $16 \mathrm{~S}$ - RLEP

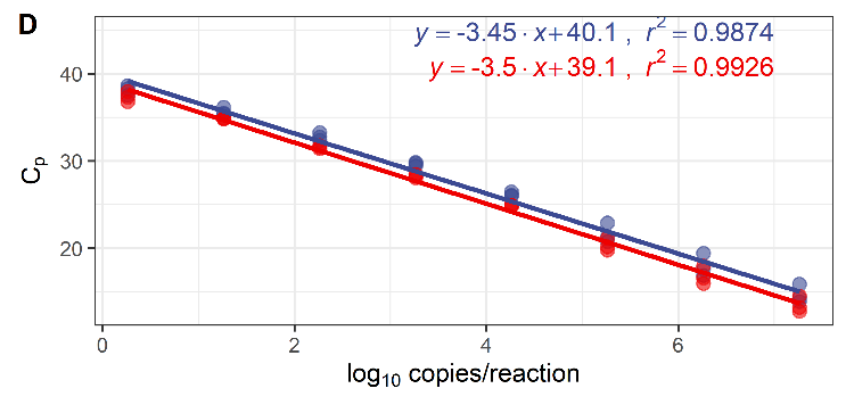

$-16 S-$ RLEP 
medRxiv preprint doi: https://doi.org/10.1101/2021.10.04.21264517; this version posted October 5, 2021. The copyright holder for this preprint (which was not certified by peer review) is the author/funder, who has granted medRxiv a license to display the preprint in It is made available under a CC-BY-NC-ND 4.0 International license.

278 Fig 1. Standard curves of the amplification of 16SrRNA and RLEP targets in M. leprae

279 DNA and in a synthetic construct. Panels A and C show the calibration curves obtained 280 using M. leprae DNA, diluted in total DNA extracted from M. leprae-negative whole blood. 281 Continuous lines show the linear range and the dashed lines are extrapolations towards the 282 non-linear range. Efficiencies calculated from the linear ranges were $99.2 \%$ for $16 \mathrm{SrRNA}$ 283 and $102.2 \%$ for RLEP, and $r^{2}$ were 0.9968 and 0.9987 , respectively. Panels $B$ and D show 284 the calibration curves obtained using a synthetic gene containing one copy of each target 285 per molecule, diluted in total DNA extracted from M. leprae-negative whole blood. The 286 efficiencies were $94.9 \%$ for 16 SrRNA and $93 \%$ for RLEP, and $r^{2}$ were 0.9874 and 0.9926 , 287 respectively.

289 The analytical $95 \%$ limit of detection $\left(\operatorname{LoD}_{95 \%}\right)$ was determined from a series of tests in which 290 DNA extracted from M. leprae was diluted from $5 \mathrm{ng}$ to $100 \mathrm{ag} /$ reaction. Figure 2 shows the 291 fitted Probit models and the obtained LoD $_{95 \%}$ for $16 \mathrm{~S}$ rRNA and RLEP, which were 292 experimentally determined as approximately $450 \mathrm{fg}$ of DNA (ca. $126 \mathrm{M}$. leprae genomes) for 293 the 16SrRNA gene and about $4.60 \mathrm{fg}$ of DNA (ca. 1.3 M. leprae genomes) for the RLEP 294 gene. 
medRxiv preprint doi: https://doi.org/10.1101/2021.10.04.21264517; this version posted October 5, 2021. The copyright holder for this preprint (which was not certified by peer review) is the author/funder, who has granted medRxiv a license to display the preprint in It is made available under a CC-BY-NC-ND 4.0 International license.

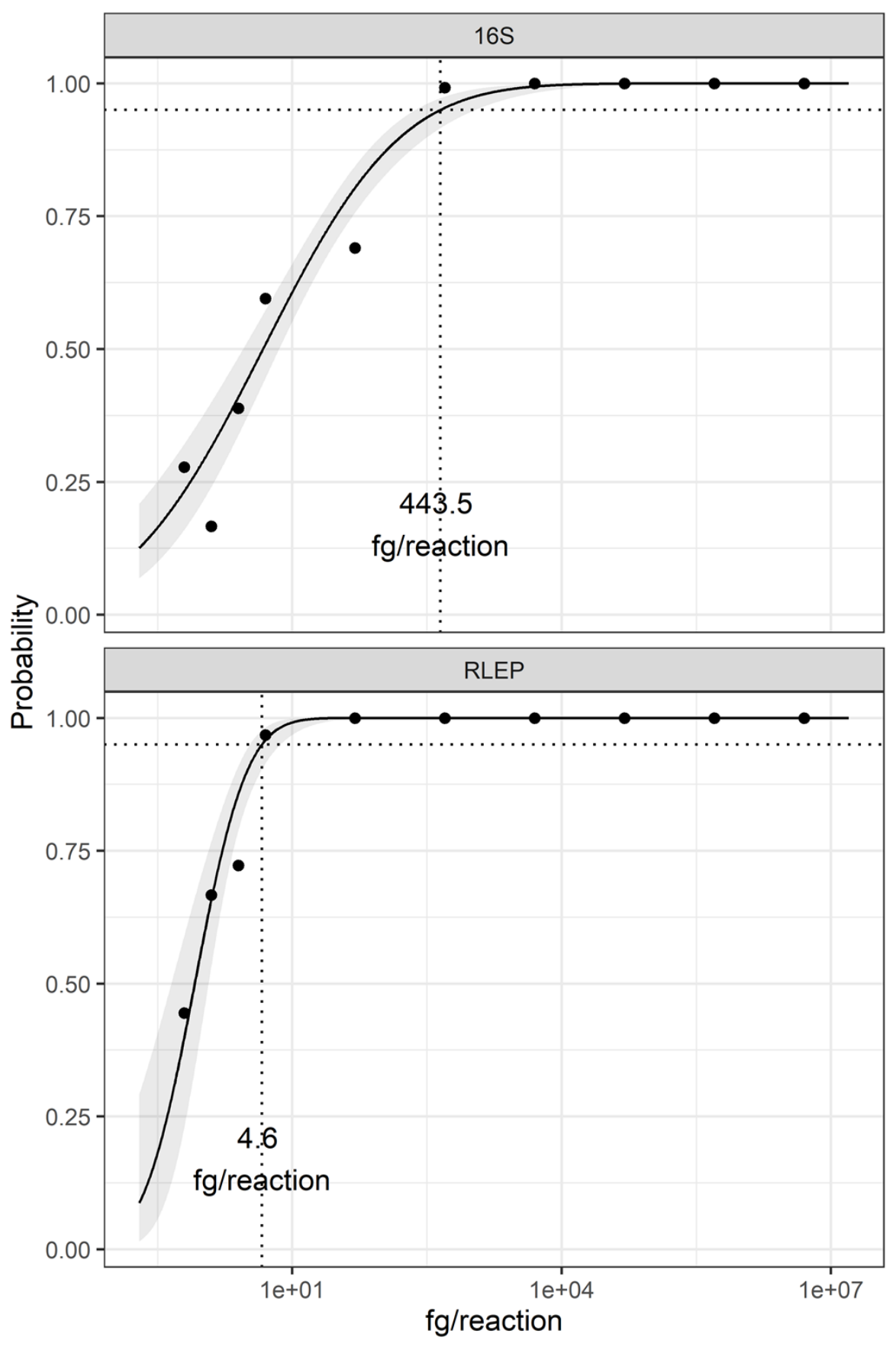

297 Fig 2. Analytical 95\% limit of detection (LoD ${ }_{95 \%}$ ) for 16SrRNA and RLEP in multiplexed 298 qPCR. Mycobacterium leprae DNA was diluted in DNA extracted from whole blood from 299 healthy donors and tested from $5 \mathrm{ng}$ to $0.5 \mathrm{fg} /$ reaction. Probability of detection was 300 calculated for 16 S and RLEP (tom and bottom panels, respectively) from nine independent 301 experiments, and a Probit model was fit to the data (black lines). The grey ribbon around 302 the model fit indicates the $95 \% \mathrm{Cl}$ on the predicted probability. Dotted lines indicate the 
medRxiv preprint doi: https://doi.org/10.1101/2021.10.04.21264517; this version posted October 5, 2021. The copyright holder for this preprint (which was not certified by peer review) is the author/funder, who has granted medRxiv a license to display the preprint in It is made available under a CC-BY-NC-ND 4.0 International license.

303 interpolation to determine the concentration at a $95 \%$ probability. The calculated $\operatorname{LoD}_{95 \%}$ is 304 displayed on each plot in femtograms of DNA/reaction.

The developed multiplex reaction was evaluated against a collection of microorganisms to assess the specificity of the primers and probes under these conditions. The selection 308 included several mycobacteria, as well as a few other pathogens associated with skin 309 diseases such Leishmania (figure 3). We only considered any species as cross-reactive if 310 all the technical replicates displayed amplification for at least one of the targets which was 311 not the case for any of the species tested. Most positive amplifications observed correspond 312 to RLEP, which was detected in two out of three replicates in M. fortuitum and M. kyroniense. 313 Even though some reactions presented 16S rRNA signals above the threshold, these 314 amplifications are very uncharacteristic and are easily distinguishable from a proper amplification when compared with the positive control with $500 \mathrm{fg} /$ reaction of $M$. leprae.

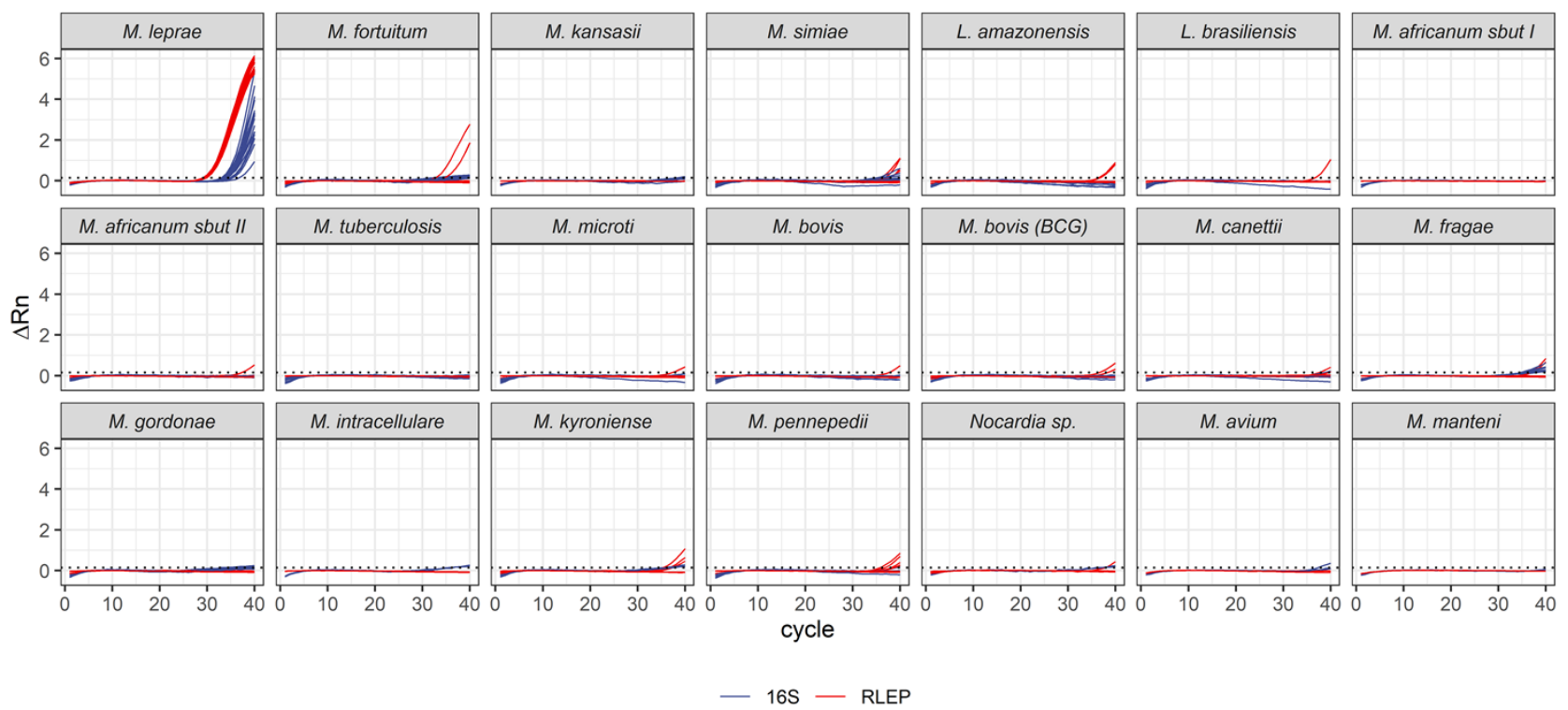

318 Fig 3. Analytical specificity for the 16SrRNA and RLEP multiplexed reactions.

319 Extracted DNA from the indicated microorganisms (5 $\mathrm{ng} / \mu \mathrm{L}$ each) were used in the 
medRxiv preprint doi: https://doi.org/10.1101/2021.10.04.21264517; this version posted October 5, 2021. The copyright holder for this preprint (which was not certified by peer review) is the author/funder, who has granted medRxiv a license to display the preprint in It is made available under a CC-BY-NC-ND 4.0 International license .

320 multiplexed reactions performed in technical triplicates in two independent experiments.

321 Results are compared to the amplification plot for $100 \mathrm{fg} M$. leprae $\mathrm{DNA} / \mu \mathrm{L}$ (top-left panel).

322 Amplification profiles are shown for each target, and each line corresponds to one individual 323 well. The dotted lines indicate the threshold for RLEP (which is the highest of the two $M$. 324 leprae targets, at 0.2).

\section{Repeatability and reproducibility}

327 Three independent operators performed three replicate runs each, in consecutive days, and 328 evaluated the repeatability and reproducibility of the multiplex reactions. For each replicate, 329 a new dilution series for the synthetic gene was prepared from a concentrated aliquot to be 330 used as template. Table 3 shows the relative deviations observed within and between 331 operators, respectively. The data shows that all intra-operator replicates were remarkably 332 reproducible, with only one point (Op. $1,16 \mathrm{~S}, 1.83 \times 10^{2}$ ) displaying a relative standard 333 deviation (rRSD\%) above $5 \%$, but still well below $10 \%$. The inter-operator variability was 334 also very low, and the largest variation was observed for the $16 \mathrm{~S}$ target. Nonetheless, the 335 rRSD\% was between 1.38 and 11.57 across the dilution range, which shows an excellent reproducibility for a quantitative test (see also supplementary table 2). 
medRxiv preprint doi: https://doi.org/10.1101/2021.10.04.21264517; this version posted October 5, 2021. The copyright holder for this preprint (which was not certified by peer review) is the author/funder, who has granted medRxiv a license to display the preprint in It is made available under a CC-BY-NC-ND 4.0 International license.

339 Table 3. Precision measurement for repeatibility and reproductibility.

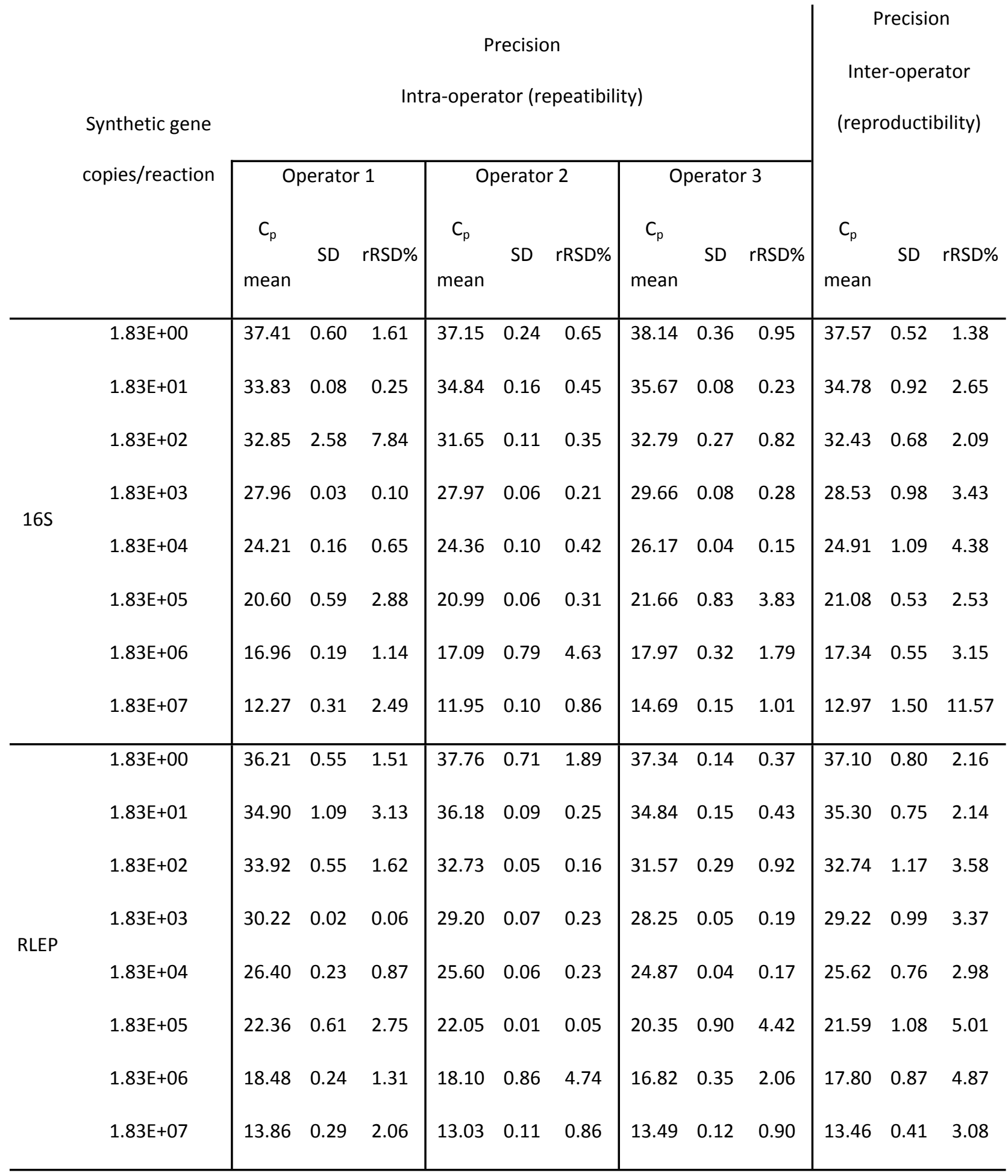

341 The accuracy of the determinations performed by the multiplex real-time qPCR assay was

342 also estimated using the synthetic DNA. To evaluate the intra- and inter-repeatability (or

343 intermediate precision) for operators, we calculated the arithmetic mean, standard deviation, 
medRxiv preprint doi: https://doi.org/10.1101/2021.10.04.21264517; this version posted October 5, 2021. The copyright holder for this preprint (which was not certified by peer review) is the author/funder, who has granted medRxiv a license to display the preprint in It is made available under a CC-BY-NC-ND 4.0 International license .

344 and relative standard deviation percentage of three independent experiments. It is 345 noteworthy that the detection of the human target 18S rRNA does follow the same dilution 346 trend for the other targets because the synthetic template was not diluted in human DNA.

347 In summary, for both $M$. leprae targets we observed that all points showed excellent 348 reproducibility and repeatability. As expected, detection of the human target 18SrRNA loses 349 reproducibility as it becomes scarce in the reaction due to the dilution factor. It is noteworthy 350 that there is no variation in the detection of the human target $18 \mathrm{~S}$ rRNA when M. leprae DNA 351 was present in the synthetic control molecule, i.e., in a 1:1 ratio, supporting the notion that 352 the multiplexed reactions do not interfere with each other (data not shown).

\section{Stability}

355 Storage stability was assessed by performing monthly evaluations of reactions with different 356 concentrations of the synthetic DNA molecule for 5 months. Most of the data points tested 357 varied below the established limit of three standard deviations above the average of all time 358 points. Figure 4 shows the $C_{p}$ obtained for the three evaluated targets (16SrRNA, RLEP, 359 and 18SrRNA) in representative concentrations for brevity, over a 5-month period. The test 360 remained reliable for the entire range of concentrations tested. 
medRxiv preprint doi: https://doi.org/10.1101/2021.10.04.21264517; this version posted October 5, 2021. The copyright holder for this preprint (which was not certified by peer review) is the author/funder, who has granted medRxiv a license to display the preprint in It is made available under a CC-BY-NC-ND 4.0 International license.

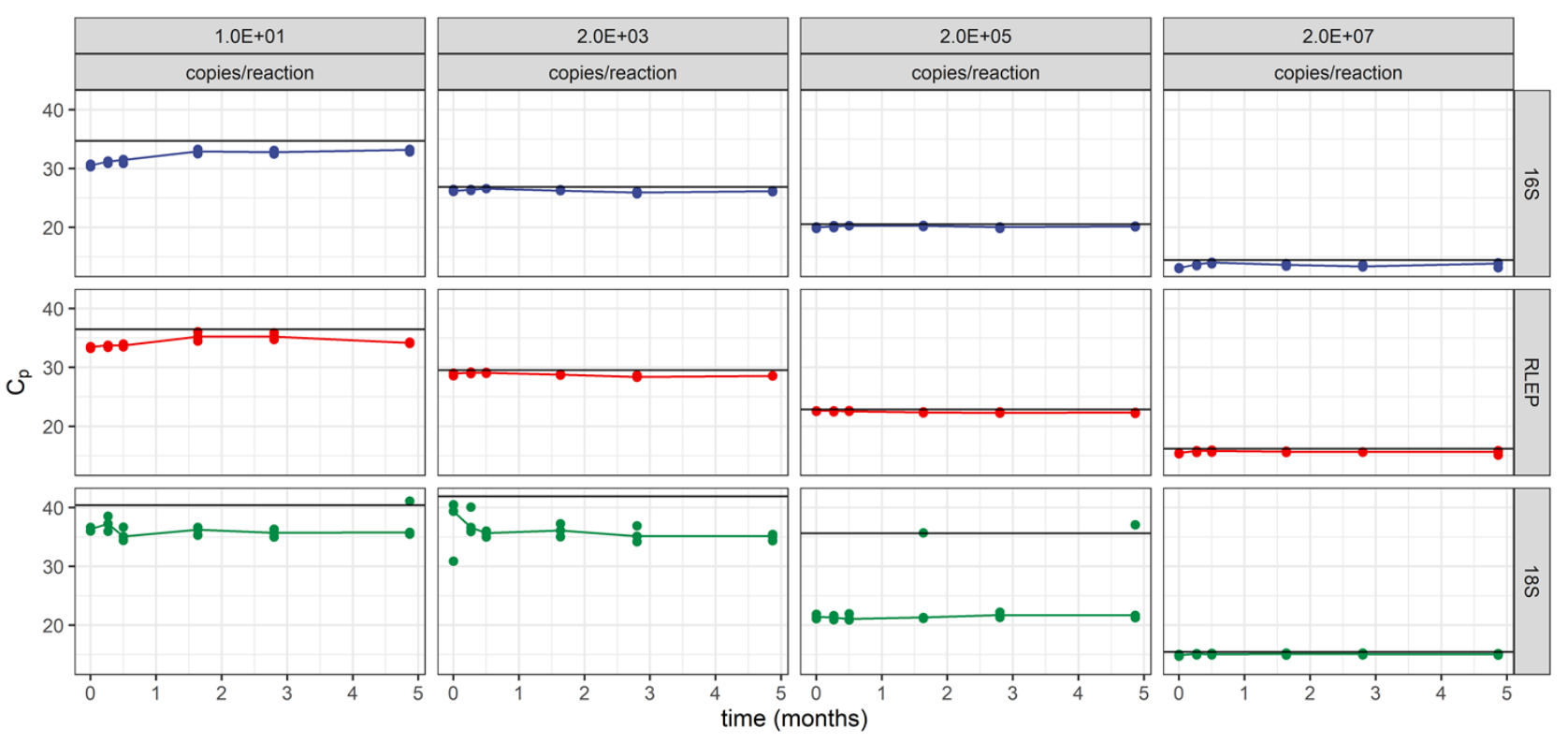

Fig 4. Stability of the reactions over five months using synthetic DNA as a template.

364 Each panel shows the $C_{p}$ values obtained for each target (lines of panels) and for each template concentration (columns of panels) over time. Points represent one technical replicate. Black horizontal lines indicate the upper tolerance limit defined as three standard deviations above the mean $\mathrm{C}_{\mathrm{p}}$ for each template concentration.

Diagnostic performance

370 The implemented setup involved the interrogation of two target sequences from M. leprae

371 to classify clinical samples correctly while mitigating possible false positives. To evaluate 372 the diagnostic performance, we first established optimal parameters for the analysis, 373 considering possible cross-reactions that may occur in the laboratory routine. Figure 5 374 shows the receiver operating characteristic (ROC) curves for a subset of the best-performing 375 combinations of cutoff values for 16 SrRNA and RLEP. Data for the full range of $C_{p}$ cutoffs 376 combinations are listed in the supplementary table 3. 
medRxiv preprint doi: https://doi.org/10.1101/2021.10.04.21264517; this version posted October 5, 2021. The copyright holder for this preprint (which was not certified by peer review) is the author/funder, who has granted medRxiv a license to display the preprint in It is made available under a CC-BY-NC-ND 4.0 International license .

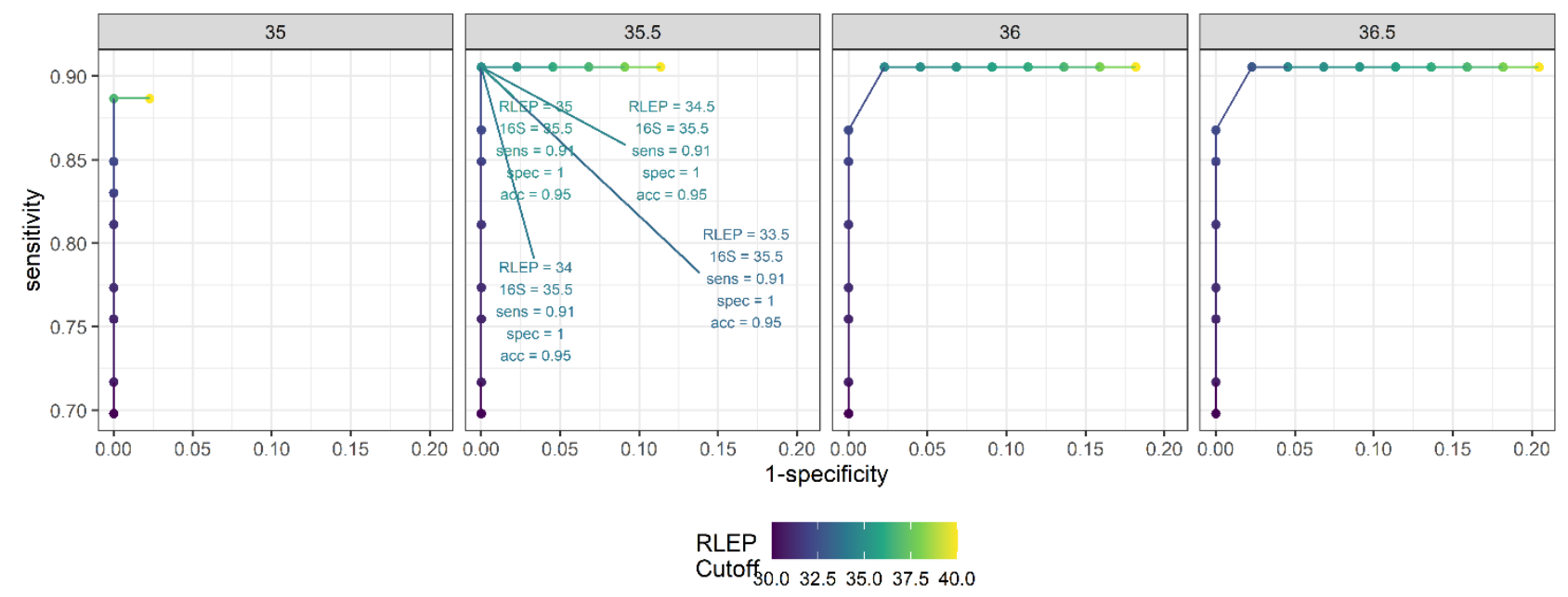

379 Fig 5. Diagnostic performance of the new multiplex qPCR. Different combinations of 380 cutoff values for 16SrRNA (panels) and RLEP (color scale) were tested on a patient panel $381(n=97)$. For each combination of cutoff values, the sensitivity and specificity were calculated 382 and plotted as ROC curves. Here, only $C_{p}$ cutoff values for 16 SrRNA between 35 and 36.5 383 are shown. The combinations resulting in a specificity of 1 and the highest sensitivity for 384 each condition are annotated.

386 Based on these results, the best combination of cutoff values (35.5 for 16SrRNA and 34.5 387 for RLEP) showed a sensitivity of $91 \%$ and specificity of $100 \%$. These parameters were 388 used to establish the decision algorithm presented in Table 4. 
medRxiv preprint doi: https://doi.org/10.1101/2021.10.04.21264517; this version posted October 5, 2021. The copyright holder for this preprint (which was not certified by peer review) is the author/funder, who has granted medRxiv a license to display the preprint in It is made available under a CC-BY-NC-ND 4.0 International license .

391 Table 4. Decision algorithm for classification of samples based on the data obtained with 392 the new multiplex qPCR.

\begin{tabular}{ll} 
Results & Classification \\
\hline 18 SrRNA negative & Extraction failure (repeat extraction) \\
18 SrRNA $C_{p}$ between 13 and 32 & Valid reaction (proceed with classification) \\
RLEP $<34.5$ and $16 S<35.5$ & M. leprae detected \\
RLEP $<34.5$ and $16 S \geq 35.5$ & Equivocal (mark patient for new sample \\
& collection and testing) \\
RLEP $\geq 34.5$ & M. leprae undetected
\end{tabular}

394 Next, the molecular diagnosis obtained using the new multiplex PCR, was compared to the 395 clinical diagnosis of each sample (Figure 6 and supplementary table 4). Results show that 396 the qPCR reaction and classification algorithm correctly characterized 48 of the 53 samples 397 previously described as "Leprosy" by the clinical outcome. Of the 5 misclassified samples, 398 one was classified as negative for M. leprae and four were in the "equivocal" quadrant. The 399 Bacterial load for the 5 misclassified samples were 0. 
medRxiv preprint doi: https://doi.org/10.1101/2021.10.04.21264517; this version posted October 5, 2021. The copyright holder for this preprint (which was not certified by peer review) is the author/funder, who has granted medRxiv a license to display the preprint in It is made available under a CC-BY-NC-ND 4.0 International license.
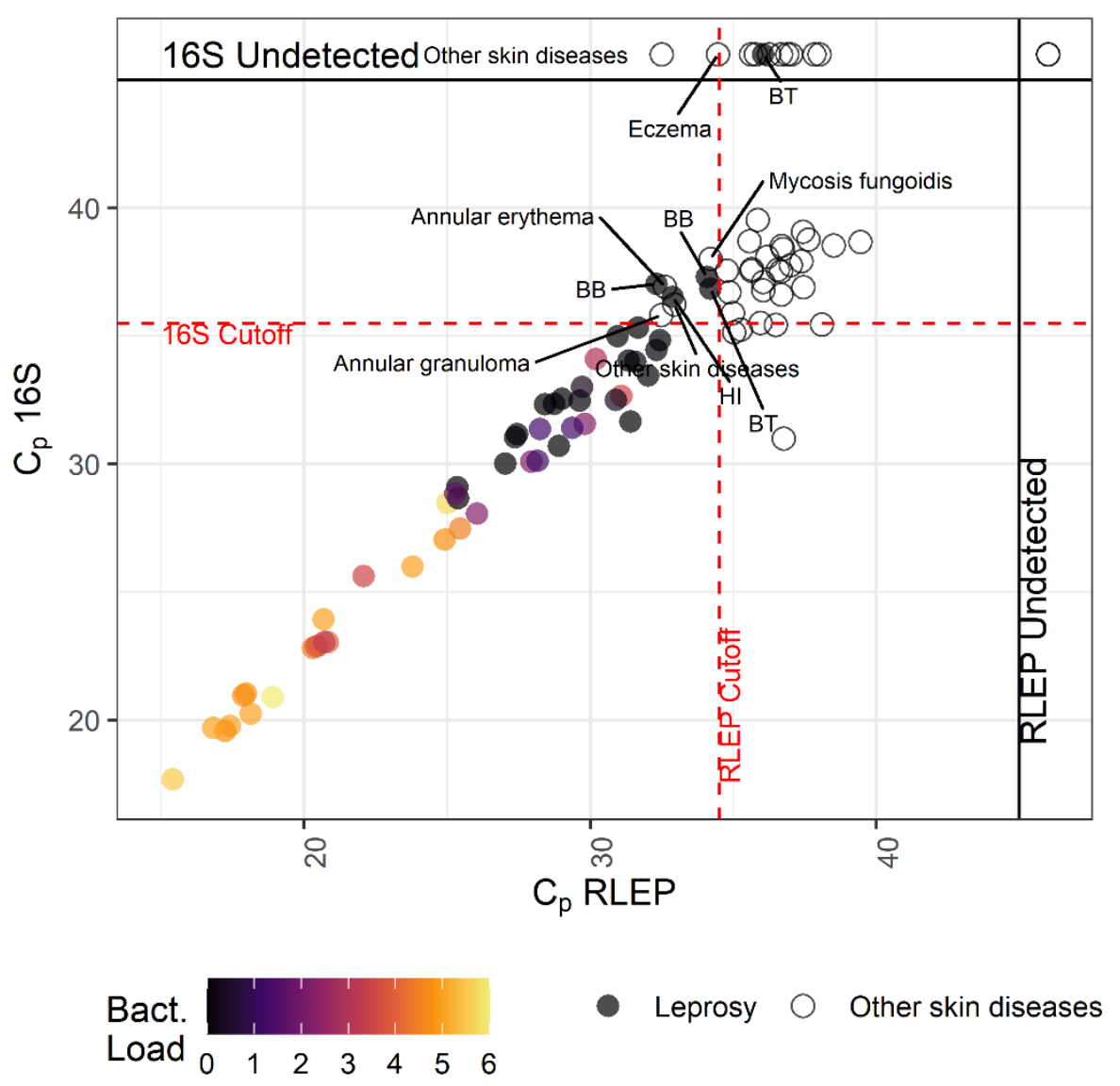

402 Fig 6. Distribution of $\mathrm{C}_{\mathrm{p}}$ values obtained for the training panel. Each point represents a 403 different sample (mean $\mathrm{C}_{p}$ s of a technical duplicate). Filled circles represent leprosy samples 404 and open dots represent negative samples, as defined by the clinical assessment. Points 405 aligned to the top and right margins indicate samples in which 16SrRNA or RLEP, 406 respectively, were not detected within 45 cycles. Bacterial load is show as a color gradient 407 (samples for which bacterial load information was not available are filled in grey). Dotted red 408 lines indicate the cutoff values from Table 3. Equivocal or misclassified samples are 409 annotated with the operational classification (false negatives) or with the diagnosis for clinic410 negative samples. 
medRxiv preprint doi: https://doi.org/10.1101/2021.10.04.21264517; this version posted October 5, 2021. The copyright holder for this preprint (which was not certified by peer review) is the author/funder, who has granted medRxiv a license to display the preprint in It is made available under a CC-BY-NC-ND 4.0 International license.

412 None of the 44 samples characterized as "Other skin diseases" were classified as M. leprae-

413 positive by our reaction and decision algorithm. Thirty-eight of these samples were classified

414 as "Negative" and 6 as "equivocal".

416 Assay validation

417 Conditions established with the training cohort were tested on an independent set of 418 samples, which were previously characterized using a distinct qPCR method described in 419 Girma et al. (32). The comparison between the original classification and the new results is 420 shown in figure 7 and supplementary table 1. We tested 50 samples, of which 34 were 421 previously characterized as positive and 16 as negative.
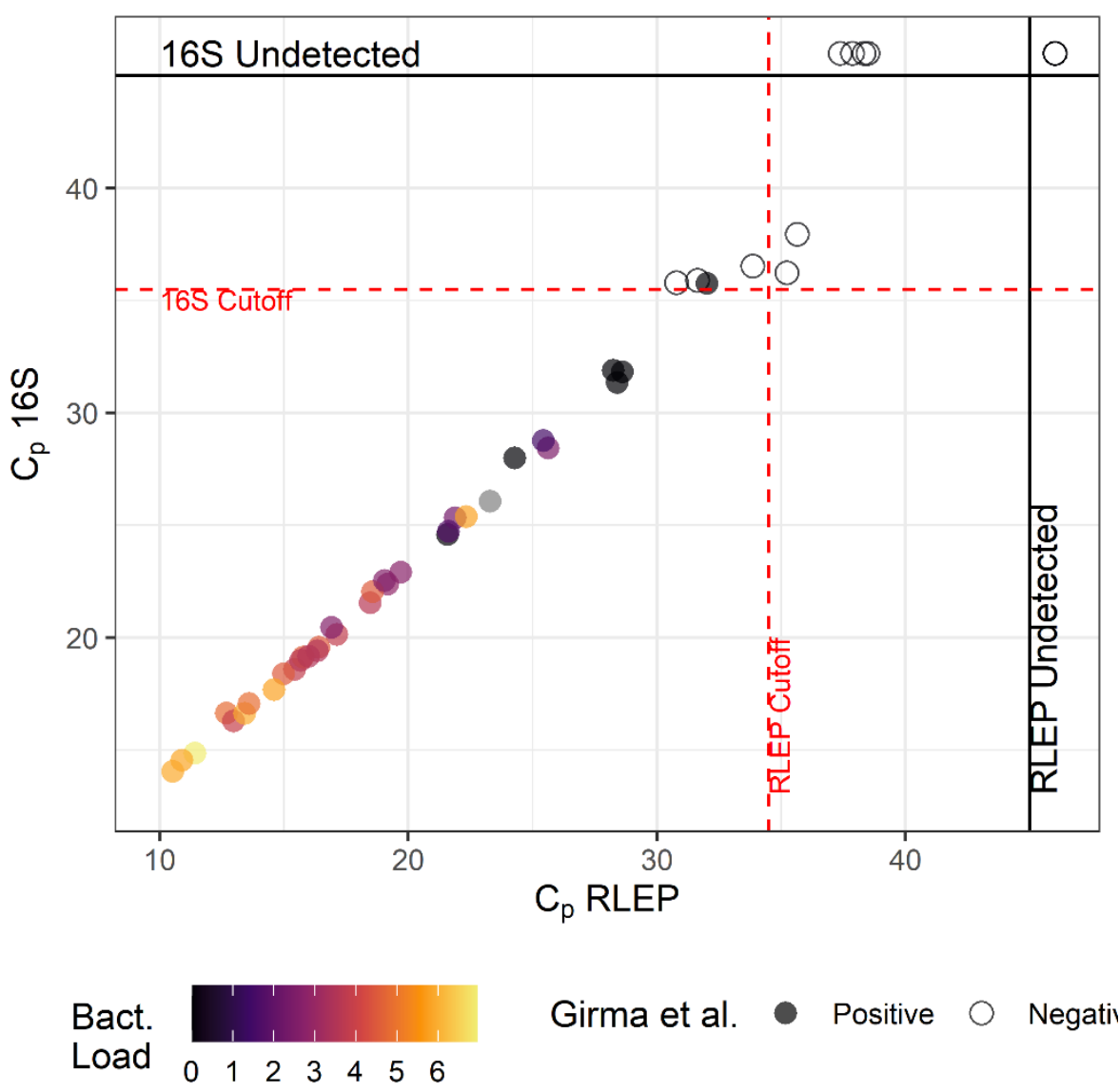
medRxiv preprint doi: https://doi.org/10.1101/2021.10.04.21264517; this version posted October 5, 2021. The copyright holder for this preprint (which was not certified by peer review) is the author/funder, who has granted medRxiv a license to display the preprint in It is made available under a CC-BY-NC-ND 4.0 International license .

424 Fig 7. Validation of parameters on a in an independent panel. Previously characterized 425 validation samples were subjected to the new qPCR described in the present study. Each 426 point represents a different sample. Filled circles represent leprosy samples and open dots 427 represent negative samples, as defined by Girma et al. Points aligned to the top and right 428 margins indicate samples in which 16SrRNA or RLEP, respectively, were not detected within 42945 cycles. Bacterial load is show as a color gradient (samples for which bacterial load 430 information was not available are filled in grey). Dotted red lines indicate the cutoff values 431 from Table 3.

433 The 50 samples were classified according to our algorithm, resulting in 33 correctly classified 434 as positive and 11 correctly classified as negative. Of the four samples classified as 435 equivocal, two were negative for the reference method and one was positive according to 436 Girma et al (32). The sensitivity, specificity and accuracy calculated for this sample set were $43797.1 \%, 100 \%$ and $98 \%$, respectively. 
medRxiv preprint doi: https://doi.org/10.1101/2021.10.04.21264517; this version posted October 5, 2021. The copyright holder for this preprint (which was not certified by peer review) is the author/funder, who has granted medRxiv a license to display the preprint in It is made available under a CC-BY-NC-ND 4.0 International license.

\section{Discussion}

440 Leprosy is a chronic infectious disease presenting great diversity of clinical forms with

441 distinct immunological and histopathological features. Leprosy can be tuberculoid, which is 442 a localized form exhibiting few or no bacteria, or lepromatous, which is a systemic form with 443 high loads of mycobacteria. Among the tuberculoid patients, there is a range of skin 444 granulomatous diseases phenotypically comparable to leprosy (5).

445 The use of PCR for leprosy diagnosis has been extensively tested (4,16,33-44). However, 446 limitations towards the experimental designs for some published studies were identified. We 447 observed that most studies: (i) test only samples from leprosy patients, creating difficulties 448 in determining some diagnostic parameters such as specificity; (ii) were performed on small 449 sample sizes; and (iii) do not have independent validation on the same assay or an 450 evaluation of the same protocol in different centers. Furthermore, no studies have used 451 reagents produced under good manufacturing practices (GMP), a set of guidelines that allow 452 for traceability and batch-to-batch reproducibility of characteristics such as physical 453 parameters and performance of the reagents (45).

454 In this study, we solved some of these issues by (i) developing and validating an assay 455 based on the two most tested targets in the literature with better accuracy so far $(7,8,41,46)$, 456 (ii) following guidelines for validation of diagnostic tests $(45,47,48)$, and (iii) using GMP grade 457 reagents. We were also able to include a reaction for the detection of human $18 \mathrm{~S}$ gene in 458 the sample, to assess the quality of DNA extraction and reagents performance in the same 459 reaction as the $M$. leprae determination occurs.

460 RLEP and 16SrRNA are the most frequent markers used in leprosy studies, displaying PCR 461 sensitivity values up to $80 \%$ for each target. However, it is important to note that the 
medRxiv preprint doi: https://doi.org/10.1101/2021.10.04.21264517; this version posted October 5,2021 . The copyright holder for this preprint (which was not certified by peer review) is the author/funder, who has granted medRxiv a license to display the preprint in It is made available under a CC-BY-NC-ND 4.0 International license .

462 sensitivity of targets varied between sample types, clinical settings, and also between 463 studies of the same authors $(8,9)$. Tatipally et al. (9) showed that using more than one 464 marker in a multiplex format of conventional endpoint PCR yields significantly higher PCR 465 positivity.

466 In the currently study, a multiplex qPCR assay simultaneously amplifies two specific 467 Mycobacterium leprae targets (16SrRNA and RLEP), and the mammalian 18SrRNA gene 468 as internal reaction control. The assay validation comprised analytical performance, 469 diagnostic sensitivity and specificity, as well as reproducibility and repeatability. 470 Development of multiplex qPCR assays provides a greater challenge than designing 471 singleplex assays because it often requires extensive optimization as primer-dimers and 472 non-specific interactions may interfere with amplification of the desired targets. Additionally, 473 it is important that the amplification of two or more targets does not preferentially amplify 474 one of the targets $(49,50)$. Combining multiple primers and probes did not affect the 475 efficiency of the triplex qPCR in comparison to the corresponding singleplex reactions used 476 in Martinez et al. (16), who evaluated the independent detection of 16S and RLEP using the 477 same primers and probes and obtained 0.91 and 0.51 for sensitivity and 0.73 and 1 for 478 specificity, respectively. Barbieri et al. (4) also used the same 16 S target to evaluate 479 paucibacillary leprosy samples and obtained 0.57 for sensitivity and 0.91 for specificity. 480 Here, we evaluated a panel with 53 leprosy and 44 non-leprosy patient samples, and later 481 a different sample panel (50 patient samples) and achieved high sensitivity (> 90\%) and 482 specificity (100\%) for both panels tested.

483 However, we understand that the small number of paucibacillary (PB) individuals in our 484 study is a limitation. In fact, the greatest importance of using qPCR as a complementary 485 diagnosis is precisely for PB samples. Generally, PB patients exhibit low (or zero) bacterial 486 load and a histopathology examination that does not distinguish from the diagnosis of other 
medRxiv preprint doi: https://doi.org/10.1101/2021.10.04.21264517; this version posted October 5, 2021. The copyright holder for this preprint (which was not certified by peer review) is the author/funder, who has granted medRxiv a license to display the preprint in It is made available under a CC-BY-NC-ND 4.0 International license.

487 dermatoses. Therefore, these are the cases where clinical evaluation alone might not be 488 able to determine the diagnosis, and where a qPCR confirmation becomes more important. 489 However, due to the scarcity of bacterial DNA in these sample, it is known that the detection 490 of M. leprae in PB patients by real-time PCR is difficult (4).

491 The reactions we developed in this study predict the equivocal classification of early-stage 492 infections based on the finding from Martinez et al. (16), who showed that RLEP displays 493 higher sensitivity than 165 whereas the ribosomal gene displays higher specificity. Thus, 494 samples lacking $16 \mathrm{~S}$ amplification but with RLEP amplification with a $\mathrm{C}_{p}$ lower than the 495 threshold are suggested to be re-analyzed.

496 In general, our data (figure 6) show a correlation between $\mathrm{BI}$ and $\mathrm{C}_{\mathrm{p}}$ values. Biopsies from 497 patients with higher BI values were deemed positive for bacteria earlier in the amplification 498 cycle, as seen by the lower $\mathrm{Cp}$ values and high copy numbers of bacilli.

499 The "analytical sensitivity" or "limit of detection" of an assay is defined as the ability of the 500 assay to detect very low concentrations of a given substance in a biological specimen (45). 501 The result of the limit of detection $\left(\mathrm{LoD}_{95 \%}\right)$ determination when tested on a purified M. leprae 502 sample indicated a higher sensitivity for RLEP (4.6 fg of DNA/reaction, equivalent to 503 approximately $1.3 \mathrm{M}$. leprae genomes) versus $16 \mathrm{~S}$ (450 fg of DNA/reaction, approximately 504126 M. leprae genomes). This difference in sensitivity was expected since the 16SrRNA is 505 a single copy gene (29) and the RLEP presents an average of 36 copies per genome (26).

506 Applicability in a reference laboratory setting was also considered during the development 507 of these reactions. Intra and inter-operator variability were low, ensuring consistent results 508 in routine testing (table 3). Moreover, reagents remained stable for at least five months, 509 allowing for adequate stock maintenance (figure 4). 
medRxiv preprint doi: https://doi.org/10.1101/2021.10.04.21264517; this version posted October 5,2021 . The copyright holder for this preprint (which was not certified by peer review) is the author/funder, who has granted medRxiv a license to display the preprint in It is made available under a CC-BY-NC-ND 4.0 International license .

510 Leprosy is a silent disease with a very long incubation time. Currently, transmission can only

511 be halted if patients obtain early diagnosis. High-risk individuals, which are the patients' 512 close contacts, should be traced and treated whenever leprosy is detected. Recently, it has 513 been suggested that novel policies towards this group of contacts such as immuno- and 514 chemoprophylaxis are effective to help control the disease burden $(15,51,52)$. These 515 approaches provide a screening of the high-risk population that, coupled with a 516 pharmacological or immunological intervention, has been suggested to decrease disease 517 incidence.

518 In some situations, clinical diagnosis needs the accuracy support of a laboratory analysis, 519 and qPCR is a reliable technique to enable diagnostic confirmation (10). Indeed, we 520 confirmed that the availability of molecular tests can be very helpful in diagnosing patients 521 during contact monitoring (53). When contacts present a leprosy-like lesion, a positive PCR 522 resulted in a leprosy diagnosis with $50 \%$ sensitivity and $94 \%$ specificity (53). Other indirect 523 methods based on simultaneous detection of host humoral as well as cellular immune 524 response directed against the bacteria are also promising new diagnostic tools. Recently, 525 lateral flow assays (LFA), combining detection of mycobacterial components and host 526 proteins, proved to be specific and sensitive (54-60). The signature detected by this platform 527 identified $86 \%$ of the leprosy patients, with a specificity of $90 \%$ (AUC: $0.93, p<0.0001)(58)$. 528 Thus, a multicentric study comparing different available methods such as qPCR and LFA is 529 still necessary. It is noteworthy that our data showed accuracy, sensitivity, and specificity 530 values quite similar to LFA.

531 We believe that the diagnosis of tropical and neglected diseases needs molecular-based 532 methods such as PCR, especially due to the robustness and capillarity of the technique in 533 clinical analysis laboratories worldwide. Towards that future, we present a real-time 534 quantitative PCR produced with GMP reagents that adheres to all quality control 
medRxiv preprint doi: https://doi.org/10.1101/2021.10.04.21264517; this version posted October 5, 2021. The copyright holder for this preprint (which was not certified by peer review) is the author/funder, who has granted medRxiv a license to display the preprint in It is made available under a CC-BY-NC-ND 4.0 International license .

535 specifications, allowing batch-to-batch performance reproducibility and repeatability, and

536 that can be used in research and clinical laboratories with reasonable infrastructure in 537 endemic countries. Finally, we envision the multiplex qPCR assay developed adapted to 538 more affordable, rapid, point-of-care tests to be used in low-resourced settings, enabling on539 site early and specific diagnosis of leprosy, hopefully helping disease control.

\section{Acknowledgments}

542 The authors are grateful to the entire team of dermatologists, nurses, and technicians that

543 collaborate at the Souza Araújo Clinic from the Leprosy Laboratory at the Oswaldo Cruz

544 Institute. The authors are also grateful for the excellent technical assistance by Aline Burda 545 Farias, Nilson José Fidêncio and Sylvia Mara Bohn at IBMP. We thank the Laboratório de 546 Pesquisa em Leishmaniose (IOC- Fiocruz) and Laboratório de Biologia Molecular Aplicada 547 a Micobactérias (IOC-Fiocruz) for donating the DNA from mycobacterial samples used in 548 the analytical specificity study. 
medRxiv preprint doi: https://doi.org/10.1101/2021.10.04.21264517; this version posted October 5, 2021. The copyright holder for this preprint (which was not certified by peer review) is the author/funder, who has granted medRxiv a license to display the preprint in It is made available under a CC-BY-NC-ND 4.0 International license .

550

551

552

\section{References}

1. WHO | A guide for surveillance of antimicrobial resistance in leprosy: 2017 update. https://www.who.int/lep/resources/9789290226192/en/

2. Sarno EN, Duppre NC, Sales AM, Hacker MA, Nery JA, Matos HJ de. Leprosy exposure, infection and disease: a 25-year surveillance study of leprosy patient contacts. Mem Inst Oswaldo Cruz. 2012 Dec;107(8):1054-9.

3. Shepard CC, McRae DH. A method for counting acid-fast bacteria. Int J Lepr Other Mycobact Dis; 36(1):78-82.

4. Barbieri RR, Manta FSN, Moreira SJM, Sales AM, Nery JAC, Nascimento LPR, et al. Quantitative polymerase chain reaction in paucibacillary leprosy diagnosis: A followup study. PLoS Negl Trop Dis. 2019;13(3):e0007147.

5. Reibel F, Cambau E, Aubry A. Update on the epidemiology, diagnosis, and treatment of leprosy. Med Mal Infect. 2015;45(9):383-93.

6. White C, Franco-Paredes C. Leprosy in the 21st century. Clin Microbiol Rev. 2015;28(1):80-94.

7. Cole ST, Eiglmeier K, Parkhill J, James KD, Thomson NR, Wheeler PR, et al. Massive gene decay in the leprosy bacillus. Nature; 409(6823):1007-11.

8. Goulart IMB, Goulart LR. Leprosy: Diagnostic and control challenges for a worldwide disease. Arch Dermatol Res. 2008;300(6):269-90.

9. Tatipally S, Srikantam A, Kasetty S. Polymerase Chain Reaction (PCR) as a Potential Point of Care Laboratory Test for Leprosy Diagnosis-A Systematic Review. Trop Med Infect Dis. 2018;3(4):107. 
medRxiv preprint doi: https://doi.org/10.1101/2021.10.04.21264517; this version posted October 5, 2021. The copyright holder for this preprint (which was not certified by peer review) is the author/funder, who has granted medRxiv a license to display the preprint in It is made available under a CC-BY-NC-ND 4.0 International license .

573 10. Kralik P, Ricchi M. A basic guide to real time PCR in microbial diagnostics: Definitions, parameters, and everything. Front Microbiol. 2017;8(FEB):1-9.

11. Boehme CC, Nabeta P, Hillemann D, Nicol MP, Shenai S, Krapp F, et al. Rapid Molecular Detection of Tuberculosis and Rifampin Resistance. N Engl J Med. 2010

12. Scott L, David A, Govender L, Furrer J, Rakgokong M, Waja Z, et al. Performance of the Roche Cobas MTB Assay for the Molecular Diagnosis of Pulmonary Tuberculosis in a High HIV Burden Setting. J Mol Diagnostics. 2020;22(10):1225-1237.

13. Silva Feliciano C, José Bazzo Menon L, Maria Pala Anselmo L, Dippenaar A, Mark Warren R, Araújo Silva Jr W, et al. Xpert MTB/RIF performance to diagnose tuberculosis and rifampicin resistance in a reference centre in southern Brazil. 2019

14. Fonseca B de P, Albuquerque PC, Zicker F. Neglected tropical diseases in Brazil: lack of correlation between disease burden, research funding and output. Trop Med Int

15. Steinmann P, Reed SG, Mirza F, Hollingsworth TD, Richardus JH. Innovative tools and approaches to end the transmission of Mycobacterium leprae. Lancet Infect Dis.

16. Martinez AN, Lahiri R, Pittman TL, Scollard D, Truman R, Moraes MO, et al. Evaluation of qPCR-Based assays for leprosy diagnosis directly in clinical specimens. J Clin Microbiol. 2011 Jul 1;5(10):1-8.

17. Nobre ML, Amorim FM, de Souza MCF, de Neves-Manta FS, Esquenazi D, Moraes 
medRxiv preprint doi: https://doi.org/10.1101/2021.10.04.21264517; this version posted October 5, 2021. The copyright holder for this preprint (which was not certified by peer review) is the author/funder, who has granted medRxiv a license to display the preprint in It is made available under a CC-BY-NC-ND 4.0 International license.

2017;88(4):510-9.

18. da Silva Martinez T, Nahas AA, Figueira MMR, Costa A V., Gonçalves MA, Goulart LR, et al. Oral lesion in leprosy: Borderline tuberculoid diagnosis based on detection of mycobacterium leprae DNA by qPCR. Acta Derm Venereol. 2011;91(6):704-7.

19. Gama RS, Gomides TAR, Gama CFM, Moreira SJM, de Neves Manta FS, de Oliveira LBP, et al. High frequency of M. leprae DNA detection in asymptomatic household

20. Reis EM, Araujo S, Lobato J, Neves AF, Costa AV, Gonçalves MA, et al. Mycobacterium leprae DNA in peripheral blood may indicate a bacilli migration route and high-risk for leprosy onset. Clin Microbiol Infect. 2014 ;20(5):447-52.

21. Goulart IMB, Cardoso AM, Santos MS, Gonçalves MA, Pereira JE, Goulart LR.

22. Caleffi KR, Hirata RDC, Hirata MH, Caleffi ER, Siqueira VLD, Cardoso RF. Use of the polymerase chain reaction to detect Mycobacterium leprae in urine. Brazilian J Med

23. Maltempe FG, Baldin VP, Lopes MA, Siqueira VLD, Scodro RBDL, Cardoso RF, et al. Critical analysis: Use of polymerase chain reaction to diagnose leprosy. Brazilian J Pharm Sci. 2016;52(1):163-9.

24. Azevedo M de CS, Ramuno NM, Fachin LRV, Tassa M, Rosa PS, Belone A de FF, et al. qPCR detection of Mycobacterium leprae in biopsies and slit skin smear of different leprosy clinical forms. Brazilian J Infect Dis. 2017;21(1):71-8. 
medRxiv preprint doi: https://doi.org/10.1101/2021.10.04.21264517; this version posted October 5, 2021. The copyright holder for this preprint (which was not certified by peer review) is the author/funder, who has granted medRxiv a license to display the preprint in It is made available under a CC-BY-NC-ND 4.0 International license .

assay for the detection of Mycobacterium leprae pra gene to study subclinical infection in a community. Microb Pathog. 2017;104:336-9.

26. Truman RW, Andrews PK, Robbins NY, Adams LB, Krahenbuhl JL, Gillis TP. Enumeration of Mycobacterium leprae Using Real-Time PCR. Small PLC, editor. PLoS Negl Trop Dis. 2008 Nov 4;2(11):e328.

27. Banerjee S, Sarkar K, Gupta S, Mahapatra PS, Gupta S, Guha S, et al. Multiplex PCR technique could be an alternative approach for early detection of leprosy among close contacts - a pilot study from India. BMC Infect Dis. 2010;10:1-8.

28. Donoghe HD, Holton J, Spigelman M. PCR primers that can detect low levels of Mycobacterium leprae DNA. J Med Microbiol. 2001;50(2):177-82.

29. Martinez AN, Lahiri R, Pittman TL, Scollard D, Truman R, Moraes MO, et al. Molecular Determination of Mycobacterium leprae Viability by Use of Real-Time PCR. J Clin Microbiol. 2009;47(7):2124-30.

30. Manta FS de N, Leal-Calvo T, Moreira SJM, Marques BLC, Ribeiro-Alves M, Rosa PS, et al. Ultra-sensitive detection of Mycobacterium leprae: DNA extraction and PCR

31. Ridley D, Jopling W. Classification of leprosy according to immunity. A five-group system. Int J Lepr Other Mycobact Dis. 1966;34(3):255-73.

32. Girma S, Avanzi C, Bobosha K, Desta K, Idriss MH, Busso P, et al. Evaluation of Auramine $\mathrm{O}$ staining and conventional PCR for leprosy diagnosis: A comparative cross-sectional study from Ethiopia. PLoS Negl Trop Dis. 2018;12(9):1-14.

33. Kramme S, Bretzel G, Panning M, Kawuma J, Drosten C. Detection and quantification of Mycobacterium leprae in tissue samples by real-time PCR. Med Microbiol Immunol. 
medRxiv preprint doi: https://doi.org/10.1101/2021.10.04.21264517; this version posted October 5, 2021. The copyright holder for this preprint (which was not certified by peer review) is the author/funder, who has granted medRxiv a license to display the preprint in It is made available under a CC-BY-NC-ND 4.0 International license .

2004;193(4):189-93.

643 34. Patrocínio LG, Goulart IMB, Goulart LR, Patrocínio JA, Ferreira FR, Fleury RN. Detection of Mycobacterium leprae in nasal mucosa biopsies by the polymerase chain

35. Phetsuksiri B, Rudeeaneksin J, Supapkul P, Wachapong S, Mahotarn K, Brennan PJ. A simplified reverse transcriptase PCR for rapid detection of Mycobacterium leprae in skin specimens. FEMS Immunol Med Microbiol. 2006;48(3):319-28.

36. Da Cunha FMB, Werneck MCM, Scola RH, Werneck LC. Pure neural leprosy: Diagnostic value of the polymerase chain reaction. Muscle and Nerve.

37. Santos AR, De Miranda AB, Sarno EN, Suffys PN, Degrave WM. Use of PCRmediated amplification of Mycobacterium leprae DNA in different types of clinical samples for the diagnosis of leprosy. J Med Microbiol. 1993 Oct 1;39(4):298-304.

38. Scollard DM, Gillis TP, Williams DL. Polymerase chain reaction assay for the detection and identification of Mycobacterium leprae in patients in the United States. Am J Clin

39. Martinez AN, Britto CFPC, Nery JAC, Sampaio EP, Jardim MR, Sarno EN, et al. Evaluation of real-time and conventional PCR targeting complex 85 genes for detection of Mycobacterium leprae DNA in skin biopsy samples from patients diagnosed with leprosy. J Clin Microbiol. 2006;44(9):3154-9.

40. Rudeeaneksin J, Srisungngam S, Sawanpanyalert P, Sittiwakin T, Likanonsakul S, Pasadorn S, et al. LightCycler ${ }^{\mathrm{TM}}$ real-time PCR for rapid detection and quantitation of Mycobacterium leprae in skin specimens. FEMS Immunol Med Microbiol. 
medRxiv preprint doi: https://doi.org/10.1101/2021.10.04.21264517; this version posted October 5, 2021. The copyright holder for this preprint (which was not certified by peer review) is the author/funder, who has granted medRxiv a license to display the preprint in It is made available under a CC-BY-NC-ND 4.0 International license.

2008;54(2):263-70.

41. Martinez AN, Talhari C, Moraes MO, Talhari S. PCR-Based Techniques for Leprosy Diagnosis: From the Laboratory to the Clinic. Franco-Paredes C, editor. PLoS Negl Trop Dis. 2014 Apr 10;8(4):e2655.

42. Tiwari V, Malhotra K, Khan K, Maurya PK, Singh AK, Thacker AK, et al. Evaluation of polymerase chain reaction in nerve biopsy specimens of patients with Hansen's disease. J Neurol Sci. 2017;380:187-90.

43. Carvalho RS, Foschiani IM, Renata M, Nogueira S, Marta SN. Early detection of M . leprae by qPCR in untreated patients and their contacts : results for nasal swab and palate mucosa scraping Early detection of M . leprae by qPCR in untreated patients

44. Woods SA, Cole ST. A rapid method for the detection of potentially viable Mycobacterium leprae in human biopsies: a novel application of PCR. FEMS Microbiol Lett. 1989 Dec;53(3):305-9.

45. Burd EM. Validation of laboratory-developed molecular assays for infectious diseases. Clin Microbiol Rev. 2010;23(3):550-76.

46. Turankar RP, Pandey S, Lavania M, Singh I, Nigam A, Darlong J, et al. Comparative evaluation of PCR amplification of RLEP, 16S rRNA, rpoT and Sod A gene targets for

47. Mattocks CJ, Morris MA, Matthijs G, Swinnen E, Corveleyn A, Dequeker E, et al. A standardized framework for the validation and verification of clinical molecular genetic 
medRxiv preprint doi: https://doi.org/10.1101/2021.10.04.21264517; this version posted October 5, 2021. The copyright holder for this preprint (which was not certified by peer review) is the author/funder, who has granted medRxiv a license to display the preprint in It is made available under a CC-BY-NC-ND 4.0 International license .

tests. Eur J Hum Genet. 2010;18(12):1276-88.

689

690

691

692

693

694

695

696

697

698

699

700

701

702

703

704

705

706

707

708

709

710

48. National Association of Testing Authorities A (NATA). Guidelines for the validation and verification of chemical methods. 2013;(December 2006:1-6.

49. Markoulatos $\mathrm{P}$, Siafakas $\mathrm{N}$, Moncany M. Multiplex polymerase chain reaction: A practical approach. J Clin Lab Anal. 2002;16(1):47-51.

50. Lorenz TC. Polymerase Chain Reaction: Basic Protocol Plus Troubleshooting and Optimization Strategies. J Vis Exp. 2012;63:3998.

51. Gillini L, Cooreman E, Wood T, Pemmaraju VR, Saunderson P. Global practices in regard to implementation of preventive measures for leprosy. Phillips RO, editor. PLoS Negl Trop Dis. 2017;11(5):e0005399.

52. Richardus JH, Tiwari A, Barth-jaeggi T, Arif MA, Banstola NL, Baskota R, et al. Leprosy post-exposure prophylaxis with single-dose rifampicin ( LPEP ): an international feasibility programme. 2020;(20):10-4.

53. Manta FSN, Barbieri RR, Moreira SJM, Santos PTS, Nery JAC, Duppre NC, et al. Quantitative PCR for leprosy diagnosis and monitoring in household contacts: A follow-up study, 2011-2018. Sci Rep. 2019 Dec 1;9(1):1-8.

54. Bobosha K, Tjon Kon Fat EM, van den Eeden SJF, Bekele Y, van der Ploeg-van Schip JJ, de Dood CJ, et al. Field-Evaluation of a New Lateral Flow Assay for Detection of Cellular and Humoral Immunity against Mycobacterium leprae. PLoS Negl Trop Dis. $2014 ; 8(5)$.

55. Van Hooij A, Fat EMTK, Van Den Eeden SJF, Wilson L, Da Silva MB, Salgado CG, et al. Field-friendly serological tests for determination of M. Leprae-specific antibodies. Sci Rep . 2017;7(1):1-8. 
medRxiv preprint doi: https://doi.org/10.1101/2021.10.04.21264517; this version posted October 5, 2021. The copyright holder for this preprint (which was not certified by peer review) is the author/funder, who has granted medRxiv a license to display the preprint in It is made available under a CC-BY-NC-ND 4.0 International license.

711 56. Yang S, Rothman RE. PCR-based diagnostics for infectious diseases: uses, 712 limitations, and future applications in acute-care settings. Lancet Infect Dis. 2004;4(6):337-48.

714 57. Corstjens PLAM, van Hooij A, Tjon Kon Fat EM, Alam K, Vrolijk LB, Dlamini S, et al. Fingerstick test quantifying humoral and cellular biomarkers indicative for M. leprae

58. Van Hooij A, Van Den Eeden S, Richardus R, Tjon E, Fat K, Wilson L, et al. Application of new host biomarker profiles in quantitative point-of-care tests facilitates leprosy

59. van Hooij A, Tió-Coma M, Verhard EM, Khatun M, Alam K, Tjon Kon Fat E, et al. Household Contacts of Leprosy Patients in Endemic Areas Display a Specific Innate Immunity Profile. Front Immunol. 2020;11:1-12.

60. Ti O-Coma M, Kie»basa SM, Van Den Eeden SJF, Mei H, Roy JC, Wallinga J, et al. Blood RNA signature RISK4LEP predicts leprosy years before clinical onset-NC-ND license EBioMedicine. 2021;68:103379. 
medRxiv preprint doi: https://doi.org/10.1101/2021.10.04.21264517; this version posted October 5, 2021. The copyright holder for this preprint (which was not certified by peer review) is the author/funder, who has granted medRxiv a license to display the preprint in It is made available under a CC-BY-NC-ND 4.0 International license .

728 Supplementary Appendix 1. Sequences of the synthetic DNA template control.

729

730 Supplementary Table 1. Validation multiplex real-time qPCR assay study results.

731

732 Supplementary Table 2. Reproducibility and Repeatability results from synthetic DNA.

733

734 Supplementary Table 3. List of $C_{p}$ cutoff value combinations with associated sensitivity and 735 specificity scores.

736

737 Supplementary Table 4. Individual Ct values for targets included in the multiplex real-time 738 qPCR assay (16S rRNA/RLEP/18SrRNA), sociodemographic, and laboratory variables for 739 patients samples included in this study. 
medRxiv preprint doi: https://doi.org/10.1101/2021.10.04.21264517; this version posted October 5, 2021. The copyright holder for this preprint (which was not certified by peer review) is the author/funder, who has granted medRxiv a license to display the preprint in It is made available under a CC-BY-NC-ND 4.0 International license .

\section{Author's contributions}

\section{3}

744 F.S.N.M., T.J. Wrote the manuscript and contributed equally for this study;

745 F.S.N.M., T.J., R.C.P.R., N.Z., S.M., M.R.A. designed, performed, and analyzed 746 experiments;

747 F.S.N.M., M.O.M. supervised sample collection;

748 T.J., A.D.T.C. supervised production of kit prototypes;

749 M.A.K., M.O.M. secured funding;

750 A.D.T.C., M.O.M. conceptualized the study and approved the final version of the manuscript 751 and are co-senior authors of this study. Guarantors of the integrity of the data presented. 


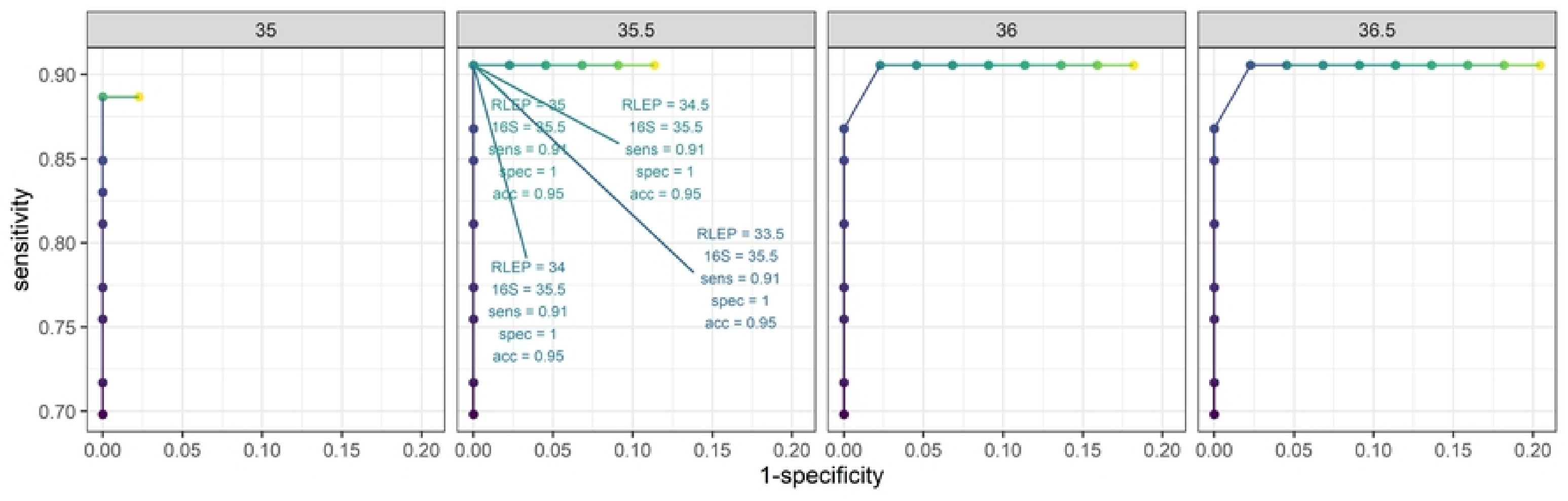

RLEP

Cutoff 30.032 .535 .037 .540 .0

Figure 


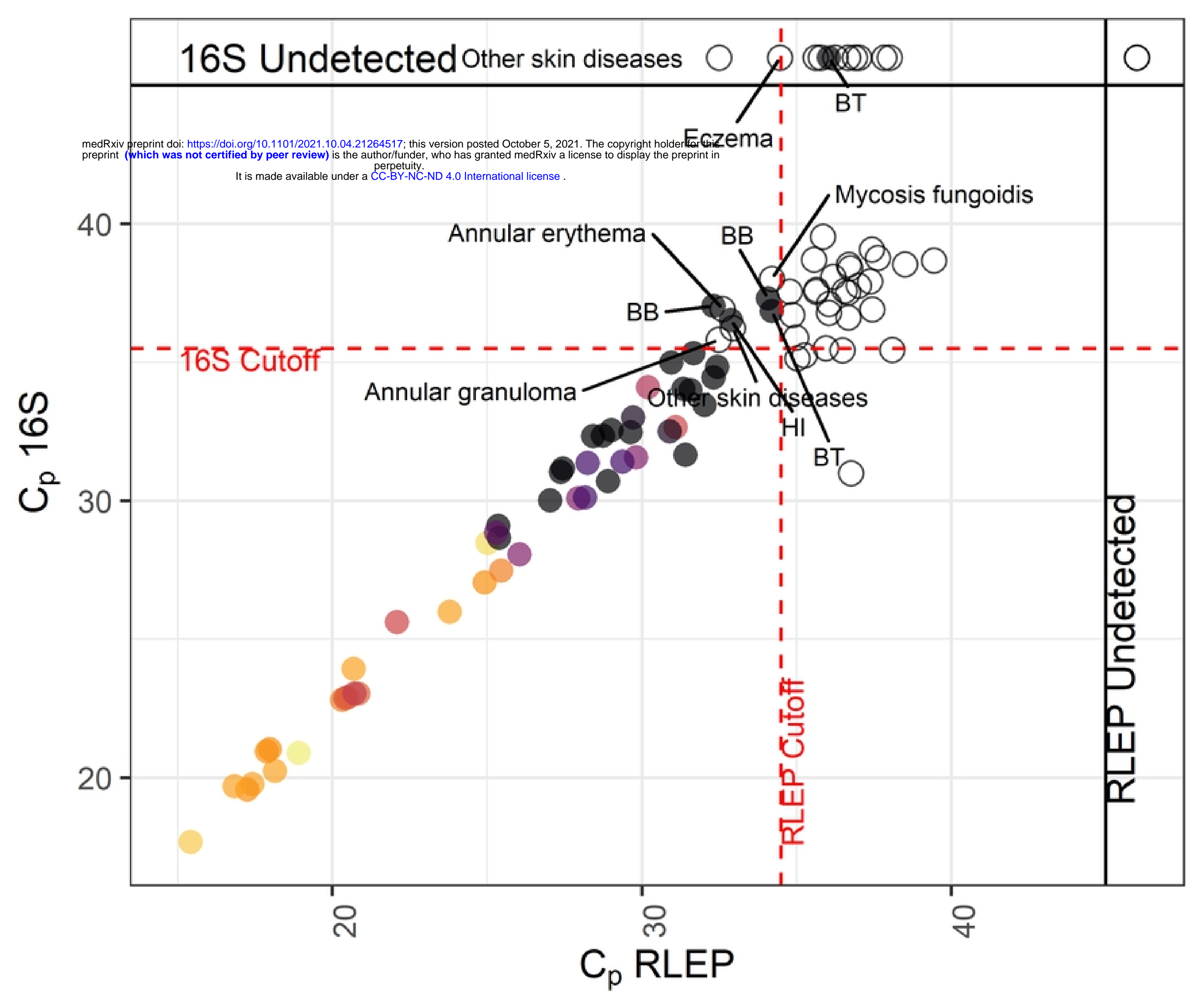

Bact.

- Leprosy $\bigcirc$ Other skin diseases Load $0 \begin{array}{llllll}0 & 2 & 3 & 4 & 5 & 6\end{array}$

Figure 


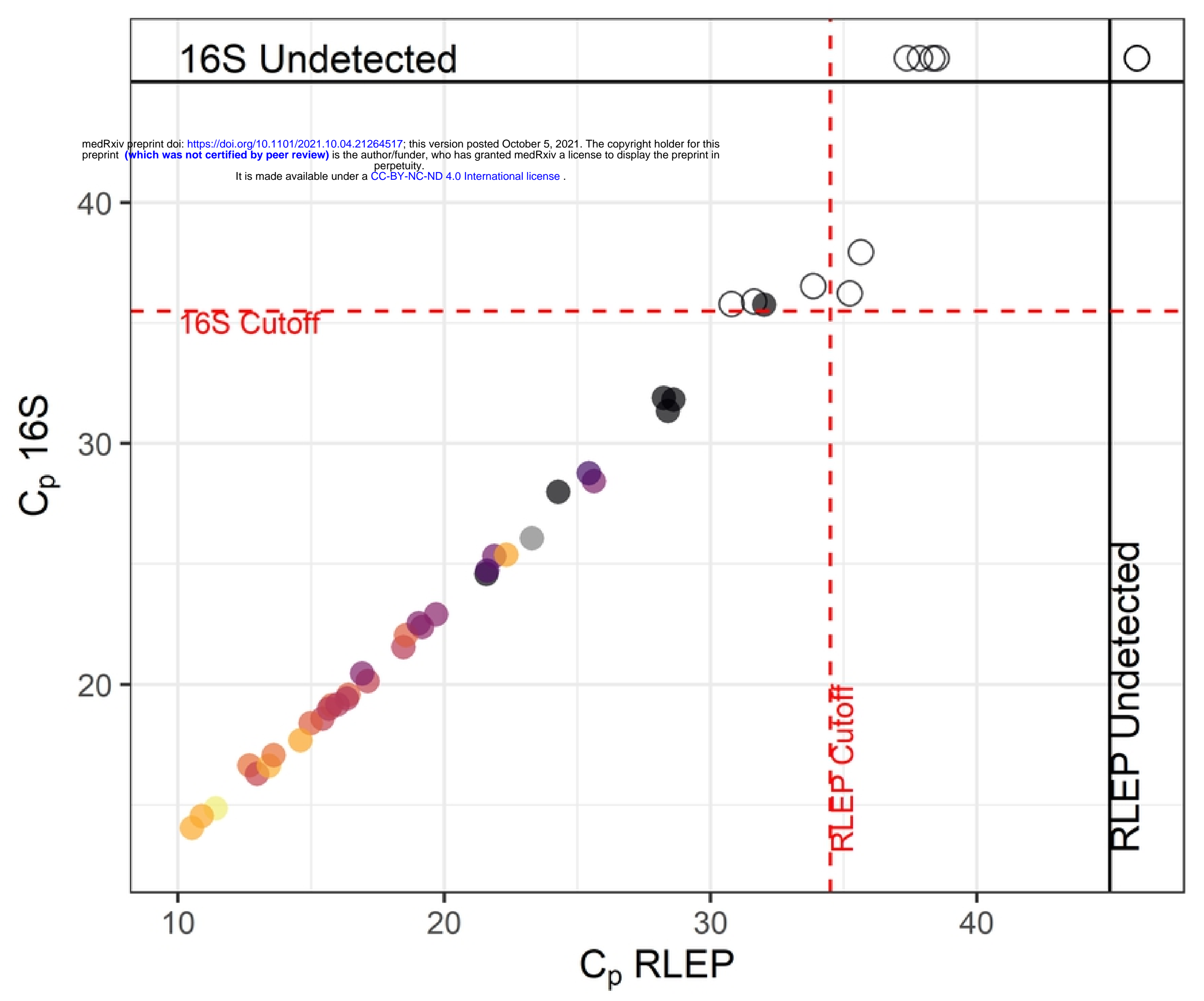

Bact.

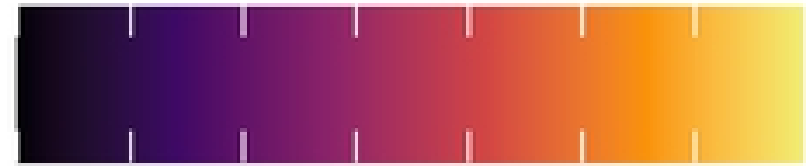

Girma et al. Positive $\bigcirc$ Negati Load

$\begin{array}{lllllll}0 & 1 & 2 & 3 & 4 & 5 & 6\end{array}$

Figure 